\title{
Final Report: Drop Testing of Aged Stems on the SP981 Reservoir
}

by

M. B. White

Westinghouse Savannah River Company

Savannah River Site

Aiken, South Carolina 29808

This paper was prepared in connection with work done under the above contract number with the U. S.

Department of Energy. By acceptance of this paper, the publisher and/or recipient acknowledges the U.S.

Government's right to retain a nonexclusive, royalty-free license in and to any copyright covering this paper, along with the right to reproduce and to authorize others to reproduce all or part of the copyrighted paper. 


\section{DISCLAIMER}

This report was prepared as an account of work sponsored by an agency of the United States Government. Neither the United States Government nor any agency thereof, nor any of their employees, makes any warranty, express or implied, or assumes any legal liability or responsibility for the accuracy, completeness, or usefulness of any information, apparatus, product, or process disclosed, or represents that its use would not infringe privately owned rights. Reference herein to any specific commercial product, process, or service by trade name, trademark, manufacturer, or otherwise does not necessarily constitute or imply its endorsement, recommendation, or favoring by the United States Government or any agency thereof. The views and opinions of authors expressed herein do not necessarily state or reflect those of the United States Government or any agency thereof.

This report has been reproduced directly from the best available copy.

Available to DOE and DOE contractors from the Office of Scientific and Technical Information, P.O. Box 62, Oak Ridge, TN 37831; prices available from (615) 576-8401.

Available to the public from the National Technical Information Service, U.S. Department of Commerce; 5285 Port Royal Road, Springfield, VA 22161. 


\section{DISCLAIMER}

Portions of this document may be illegible in electronic image products. Images are produced from the best available original document. 
Final Report: Drop Testing Of Aged Stems On The SP981 Reservoir (U)

M. Baker White

April 26, 1999

\section{APPROVALS}

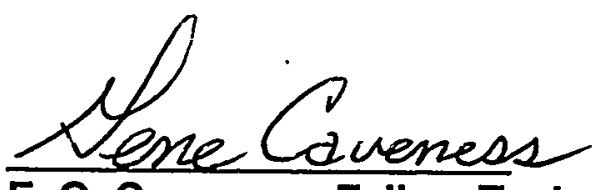

E. G. Caveness, Fellow Technical Advisor Technical Reviewer

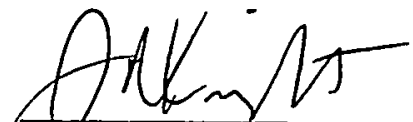

J.R. Knight, Manager

Chemical \& Hydrogen Technology Section
DATE: $5 / 10 / 99$

DATE: $5 / 12 / 9 T$ 


\section{Table of Contents}

TABLE OF TABLES

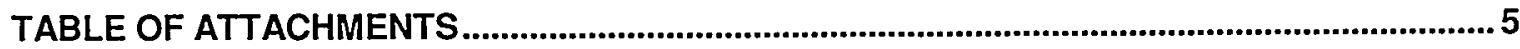

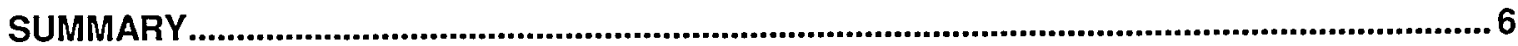

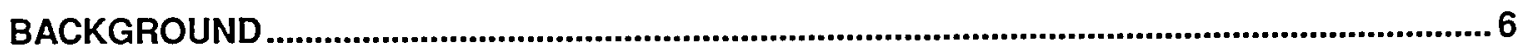

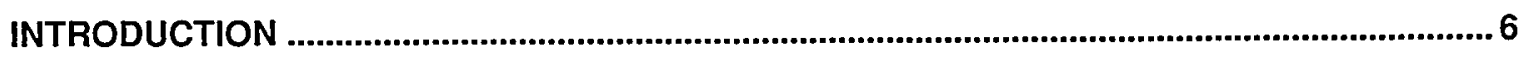

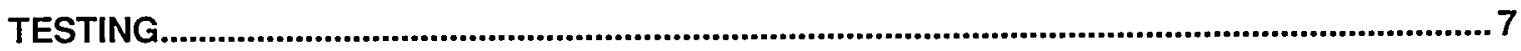

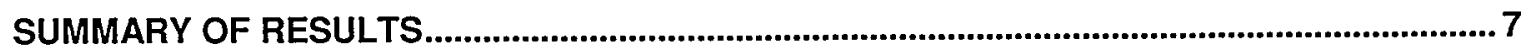

TABLE 1

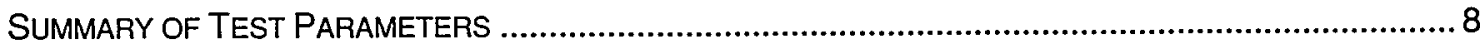

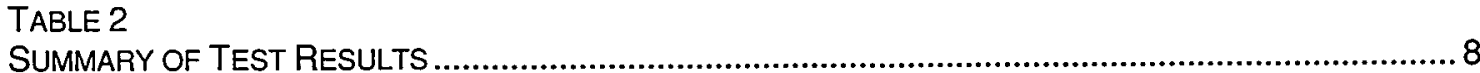

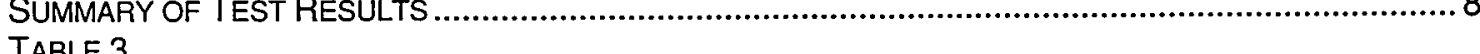

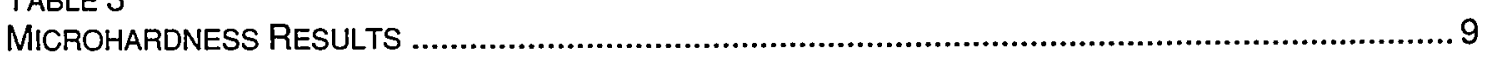

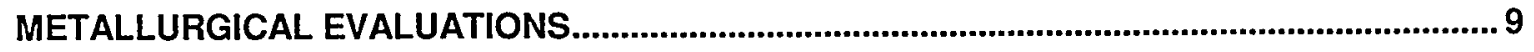

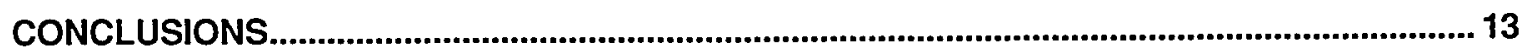

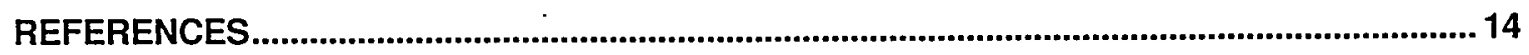

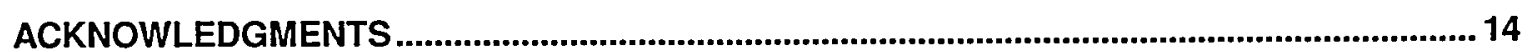




\section{Summary}

Free fall drop testing of unloaded SP981 reservoirs was conducted by Savannah River Technology Center (SRTC) in the Materials Test Facility, Building 232-H on February 2, 1999. The testing consisted of dropping eight aged and two unaged reservoirs on their stems at impact angles of $88^{\circ}$ and $70^{\circ}$ from heights of approximately 4 and 6 foot above a hardened steel surface. Representative photographs are provided in this report. A detailed description of the drop testing is found in "Preliminary Report: Drop Testing Of Aged Stems On The Sp981 Reservoir", WSRCRP-99-00220 [1]. Post drop analysis consisting of metallography and hardness testing is presented in this report.

The results showed both the aged and unaged units bent essentially as expected. Similar bend results were exhibited with the aged and unaged units, suggesting minimal, if any, degradation due to the tritium exposure and the aging process. All bent stems displayed significant metal deformation with the most severe deformation found in the $70^{\circ}-6$ foot drop reservoirs. No cracking was observed. The majority of the bent stems revealed laps on the underside of the bend due to the folding of the metal. The results also show agreement with the stem bends between the drop testing conducted by Sandia National Laboratory and the SRTC testing.

\section{Background}

Free fall drop testing of aged SP981 reservoirs was requested by Sandia National Laboratory California (SNL/CA) to assess the damage to their stems under dropping scenarios. The drop testing conducted at the Materials Test Facility, Building 232-H supplemented the drop testing previously conducted at SNL/CA with unaged units. Requests for clarification of stem robustness and advice on handling of units with bent stems from dropping have been received from the Navy through the W76 Acorn Product Realization Team (PRT). Accordingly, the need to acquire data on the handling of units with bent stems motivates this study.

\section{Introduction}

Free fall drop testing of eight unloaded aged and two unaged SP981 reservoirs was conducted on February 2, 1999 in the Materials Test Facility, Building 232- $\mathrm{H}$. The aged reservoirs were "end of life" return units from the war reserve (WR) and the unaged reservoirs were reject units that had never been loaded. SP981 reservoirs were selected for their stem configuration and represented the maximum potential for damage of stems under dropping scenarios. This report provides the results of the metallography and hardness testing conducted to assess the damage to the stems after impact with a hardened steel plate. Details of the test apparatus are documented in reference 1.

Eight SP981 reservoirs were unloaded using special unloading instructions that stipulated the specific laser drill hole location. The reservoirs were subsequently drop tested two weeks after the unloading was concluded. Each reservoir was suspended above the center of the impact plate at a predetermined drop height and impact angle. The drops were performed from heights of approximately 4 foot 3 inches ( $\left.4^{\prime} 3^{\prime \prime}\right)$ or 6 foot 6 inches (6' $6^{\prime \prime}$ ) as measured from impact surface to the end of the reservoir stem and two stem angles $\left(88^{\circ} \& 70^{\circ}\right)$. Detailed specifications on the drop testing configuration are provided in reference 1. Computer modeling and drop testing of unaged reservoirs conducted by SNL/CA indicated the two stem angles to be the most severe [2]. 


\section{Testing}

The drop testing was recorded using high-speed digital video equipment and the images downloaded onto a VCR. A review of the video images and a summary of the visual evaluation are provided below for each stem. Overall photographs of each bent stem have been recorded in reference 1. Following each visual exam, the reservoir and the pinch weld were removed from the stem. The remaining portion of the stem contained the damaged region and was examined metallographically to assess the damage. The pinch weld from two stems (S/N 4874 and S/N 16707; Tests 1 \& 3) was used to conduct autoradiography. In addition, a specimen was removed from the undamaged section of samples 4843 and 18557 for helium analysis. This helium analysis is to be submitted for testing at a later date and is outside the scope of this report.

After removal of the reservoir and pinch weld, each stem was leak checked to determine if the damage had closed the stem passage. The leak testing was performed by injecting air into the bent stem with a syringe while closing the laser drill penetration with a finger. A leak-check solution was swabbed onto the free end of the stem. The appearance of bubbles indicates an open passage through the bent stem. All stems were found to be open.

Metallographic analysis was conducted by mounting each stem in the horizontal position and performing a serial grind, with examination at selected intervals through each specimen. The grinding was conducted in about 20 mil increments as measured with a micrometer. The metallography seen in the report depicts each stem at approximately half way through each stem. Microhardness measurements were taken half way through each stem to assess the degree of cold working and metal deformation. Hardness readings were taken at mid wall on the inside and outside of each bend portion and along a straight, undamaged region. The detailed results are listed below for each stem.

\section{Summary of Results}

Table 1 provides a summary of the drop test units, test parameters and loading dates. The loaded reservoirs were unloaded on January 20,1999. Details on the drop testing configuration are provided in Reference 1 . Table 2 shows a summary of the metallurgical results and Table 3 gives the microhardness results. Following the summary Tables, a more detailed assessment of each unit is furnished. Attachments $1-10$ provide the supporting pictorial evidence. 
Table 1

Summary of Test Parameters

\begin{tabular}{|c|c|c|c|c|c|}
\hline Test & $\begin{array}{c}\text { Serial } \\
\text { Number }\end{array}$ & Condition & $\begin{array}{c}\text { Stem } \\
\text { Angle }\end{array}$ & $\begin{array}{c}\text { Drop } \\
\text { Height }\end{array}$ & $\begin{array}{c}\text { Load } \\
\text { Date }\end{array}$ \\
\hline 1 & 4874 & Aged & $88^{\circ}$ & $4^{\prime} 3^{\prime \prime}$ & $6 / 1 / 79$ \\
\hline 2 & 4863 & Aged & $88^{\circ}$ & $4^{\prime} 3^{\prime \prime}$ & $6 / 1 / 79$ \\
\hline 3 & 16707 & Aged & $70^{\circ}$ & $4^{\prime} 3^{\prime \prime}$ & $7 / 11 / 85$ \\
\hline 4 & 4843 & Aged & $70^{\circ}$ & $4^{\prime} 3^{\prime \prime}$ & $6 / 1 / 79$ \\
\hline 5 & 4007 & Aged & $70^{\circ}$ & $6^{\prime} 6^{\prime \prime}$ & $6 / 1 / 79$ \\
\hline 6 & 18557 & Aged & $70^{\circ}$ & $6^{\prime} 6^{\prime \prime}$ & $3 / 1 / 89$ \\
\hline 7 & 4818 & Aged & $88^{\circ}$ & $6^{\prime} 6^{\prime \prime}$ & $6 / 1 / 79$ \\
\hline 8 & 4025 & Aged & $88^{\circ}$ & $6^{\prime} 6^{\prime \prime}$ & $8 / 1 / 79$ \\
\hline 9 & $23350 \mathrm{~A}$ & Unaged & $70^{\circ}$ & $6^{\prime} 6^{\prime \prime}$ & $\mathrm{NA}$ \\
\hline 10 & $25826 \mathrm{~A}$ & Unaged & $88^{\circ}$ & $6^{\prime} 6^{\prime \prime}$ & $\mathrm{NA}$ \\
\hline
\end{tabular}

Table 2

Summary of Test Results

\begin{tabular}{|c|c|c|c|c|c|c|c|}
\hline Test & $\begin{array}{c}\text { Bent } \\
\text { Stem } \\
\text { Shape }\end{array}$ & $\begin{array}{c}\text { Bend } \\
\text { Location }\end{array}$ & $\begin{array}{c}\text { Bend } \\
\text { Angle }\end{array}$ & $\begin{array}{c}\text { Stem } \\
\text { Closure }\end{array}$ & $\begin{array}{c}\text { Severity of Cone } \\
\text { Damage }\end{array}$ & $\begin{array}{c}\text { OD Cracks / } \\
\text { ID Laps }\end{array}$ & $\begin{array}{c}\text { Pinch Weld } \\
\text { Damage }\end{array}$ \\
\hline 1 & "J" & Mid Stem & ---- & No & None & None & None \\
\hline 2 & "L" & Cone & $46^{\circ}$ & No & Minor Flattening & ID Laps & None \\
\hline 3 & "L" & Cone & $82^{\circ}$ & No & Minor Flattening & ID Laps & Slight Bend \\
\hline 4 & "L" & Cone & $69^{\circ}$ & No & Minor Flattening & ID Laps & None \\
\hline 5 & "L" & Cone & $44^{\circ}$ & No & Flattening & ID Laps & None \\
\hline 6 & "L" & Cone & $33^{\circ}$ & No & Flattening & ID Laps & None \\
\hline 7 & "J" & Mid Stem & ---- & No & None & None & None \\
\hline & "L" & Cone & ---- & No & Flattening & ID Laps & None \\
\hline 8 & "S" & $\begin{array}{c}\text { Mid Stem \& } \\
\text { Cone }\end{array}$ & --- & No & None & ID Laps & None \\
\hline 9 & "L" & Cone & $39^{\circ}$ & No & Flattening & ID Laps & N/A \\
\hline 10 & "S" & $\begin{array}{c}\text { Mid Stem \& } \\
\text { Cone }\end{array}$ & ---- & No & Minor Flattening & ID Laps & N/A \\
\hline
\end{tabular}


Table 3

Microhardness Results

\begin{tabular}{|c|c|c|c|c|c|c|}
\hline Test & Condition & $\begin{array}{c}\text { Bent } \\
\text { Stem } \\
\text { Shape }\end{array}$ & $\begin{array}{c}\text { Bend } \\
\text { Location }\end{array}$ & $\begin{array}{c}\text { Hardness } \\
\text { Bend ID } \\
\left(\mathrm{HV}_{500}\right)\end{array}$ & $\begin{array}{c}\text { Hardness } \\
\text { Bend OD } \\
\left(\mathrm{HV}_{500}\right)\end{array}$ & $\begin{array}{c}\text { Hardness } \\
\text { Unbent } \\
\left(\mathrm{HV}_{500}\right)\end{array}$ \\
\hline 1 & Aged & "J" & Mid Stem & 358.5 & 284.3 & 253.5 \\
\hline 2 & Aged & "L" & Cone & 311.9 & 313.0 & 208.6 \\
\hline 3 & Aged & "L" & Cone & 250.0 & 309.0 & 230.5 \\
\hline 4 & Aged & "L" & Cone & 284.0 & 306.4 & 285.5 \\
\hline 5 & Aged & "L" & Cone & 309.4 & 323.7 & 199.7 \\
\hline 6 & Aged & "L" & Cone & 340.6 & 303.8 & 224.3 \\
\hline 7 & Aged & "J" & Mid Stem & 314.5 & 281.6 & 244.0 \\
\hline & & "L" & Cone & 328.4 & 305.6 & 244.0 \\
\hline 8 & Aged & "S" & Mid Stem & 300.6 & 276.8 & 180.0 \\
\hline 9 & Unaged & "L" & Cone & 316.8 & 321.3 & 228.9 \\
\hline 10 & Unaged & "S" & Mid Stem & 301.5 & 282.4 & 172.5 \\
\hline & & "S" & Cone & 316.2 & 317.8 & 172.5 \\
\hline
\end{tabular}

\section{Metallurgical Evaluations}

\begin{tabular}{|c|c|c|c|c|c|}
\hline Test 1 & $\begin{array}{c}\text { Serial } \\
\text { Number }\end{array}$ & Condition & $\begin{array}{c}\text { Stem } \\
\text { Angle }\end{array}$ & $\begin{array}{c}\text { Drop } \\
\text { Height }\end{array}$ & $\begin{array}{c}\text { Load } \\
\text { Date }\end{array}$ \\
& 4874 & Aged & $8^{\circ}$ & $4^{\prime} 3^{\prime \prime}$ & $6 / 1 / 79$ \\
\hline
\end{tabular}

Video Tape Evaluation [Video ID \#4]:

The stem impacted first, bending into a " $\mathrm{"} \mathrm{shape} \mathrm{at} \mathrm{about} \mathrm{mid} \mathrm{stem.} \mathrm{After} \mathrm{the} \mathrm{initial} \mathrm{contact,} \mathrm{the}$ bottle impact followed with no impact to the cone.

Visual Macro Exam [See Attachment 1]:

Metal deformation was observed at the initial impact point and a slight burnish mark was found on the stem at the " $\mathrm{J}$ " bend. The laser hole was seen just above the cone and did not appear to have influenced the bending of the stem. The pinch weld was undamaged and did not influence the bending of the stem.

Metallographic Analysis:

A general wall thinning was observed in the outside diameter of the " $\mathrm{J}$ " bend as compared to the undamaged material. No crack or laps were found in either region.

Autoradiography was performed on the pinch weld to determine the extent of tritium penetration through the wall of the stem. The results show complete penetration of the stem wall. 


\begin{tabular}{|c|c|c|c|c|c|}
\hline Test 2 & $\begin{array}{c}\text { Serial } \\
\text { Number }\end{array}$ & Condition & $\begin{array}{c}\text { Stem } \\
\text { Angle }\end{array}$ & $\begin{array}{c}\text { Drop } \\
\text { Height }\end{array}$ & $\begin{array}{c}\text { Load } \\
\text { Date }\end{array}$ \\
& 4863 & Aged & $88^{\circ}$ & $4^{\prime} 3^{\prime \prime}$ & $6 / 1 / 79$ \\
\hline
\end{tabular}

Video Tape Evaluation [Video ID\#5]:

The stem impacted first, bending into a " $L$ " shape at the cone. After the initial contact, the cone impact followed. The impact of the nut was next and finally the bottle. It was noted that this type of bend was not expected for an $88^{\circ}$ drop. It appears the impact may have been less than the $88^{\circ}$ drop. However, the exact angle of impact was not determined since it was unclear whether the dropped reservoir was in a plane normal to the view of the camera.

\section{Visual Macro Exam [See Attachment 2]:}

Metal deformation was observed at the initial impact point and a slight burnish mark was found on the stem at the bend. A small amount of flattening was seen at the cone and the metal appeared to have folded as seen from beneath the bend. The laser hole was seen just above the cone and did not appear to have influenced the bending of the stem. The pinch weld was undamaged and did not influence the bending of the stem. The bend angle was found to be $46^{\circ}$ as measured from the cone.

\section{Metallographic Analysis [See Attachment 2]:}

A general wall thinning was observed in the outside diameter of the bend as compared to the undamaged material. A flattening was seen at the cone, restricting the passage. A large lap was visible of the cross section at the ID of the bend. The lap is distinguishable by the heavy metal flow parallel to the lap. Small laps were also evident in the region.

\begin{tabular}{|c|c|c|c|c|c|}
\hline Test 3 & $\begin{array}{c}\text { Serial } \\
\text { Number }\end{array}$ & Condition & $\begin{array}{c}\text { Stem } \\
\text { Angle }\end{array}$ & $\begin{array}{c}\text { Drop } \\
\text { Height }\end{array}$ & $\begin{array}{c}\text { Load } \\
\text { Date }\end{array}$ \\
16707 & Aged & $70^{\circ}$ & $4^{\prime} 3^{\prime \prime}$ & $7 / 11 / 85$ \\
\hline
\end{tabular}

Video Tape Evaluation [Video ID\#6]:

The stem impacted first, bending into a "L" shape at the cone. After the initial contact, the cone impact followed. The impact of the nut was next and finally the bottle.

\section{Visual Macro Exam [See Attachment 3]:}

Metal deformation was observed at the initial impact point and a significant burnish mark was found on the stem at the bend. The metal appeared to have folded on the ID of the bend. The laser hole was seen at mid stem and did not influence the bending of the stem. The pinch weld was slightly bent and appeared not to have influenced the bending of the stem. The bend angle was found to be $82^{\circ}$ as measured from the cone.

\section{Metallographic Analysis [See Attachment 3]:}

A general wall thinning was observed in the outside diameter of the bend as compared to the undamaged material. A lap was visible of the cross section at the ID of the bend; distinguishable by the heavy metal flow parallel to the defect.

Autoradiography was performed on the pinch weld to determine the extent of tritium penetration through the wall of the stem. The results show complete penetration of the stem wall. 


\begin{tabular}{|c|c|c|c|c|c|}
\hline Test 4 & $\begin{array}{c}\text { Serial } \\
\text { Number } \\
4843\end{array}$ & Condition & $\begin{array}{c}\text { Stem } \\
\text { Angle }\end{array}$ & $\begin{array}{c}\text { Drop } \\
\text { Height }\end{array}$ & $\begin{array}{c}\text { Load } \\
\text { Date } \\
\end{array}$ \\
& Aged & $70^{\circ}$ & $4^{\prime} 3^{\prime \prime}$ & $6 / 1 / 79$ \\
\hline
\end{tabular}

Video Tape Evaluation [Video ID\#7]:

The stem impacted first, bending into a "L" shape at the cone. After the initial contact, the cone followed with the bottle next. The nut did not contact the impact surface.

Visual Macro Exam [See Attachment 4]:

Metal deformation was observed at the initial impact point and a significant burnish mark was found on the stem at the bend. The laser hole was seen at mid stem and pinch weld showed no damage. Neither influenced the bending of the stem. The bend angle was found to be $69^{\circ}$ as measured from the cone.

Metallographic Analysis [See Attachment 4]:

A general wall thinning was observed in the outside diameter of the bend as compared to the undamaged material. A lap was visible of the cross section at the ID of the bend; distinguishable by the heavy metal flow parallel to the defect.

\begin{tabular}{|c|c|c|c|c|c|}
\hline Test 5 & $\begin{array}{c}\text { Serial } \\
\text { Number }\end{array}$ & Condition & $\begin{array}{c}\text { Stem } \\
\text { Angle }\end{array}$ & $\begin{array}{c}\text { Drop } \\
\text { Height }\end{array}$ & $\begin{array}{c}\text { Load } \\
\text { Date } \\
\end{array}$ \\
4007 & Aged & $70^{\circ}$ & $6^{\prime} 6^{\prime \prime}$ & $6 / 1 / 79$ \\
\hline
\end{tabular}

Video Tape Evaluation [Video ID\#8]:

The stem impacted first, bending into a " $\mathrm{L}$ " shape at the cone. After the initial contact, the cone, the nut and finally the bottle impact in that sequence.

Visual Macro Exam [Attachment 5]:

Metal deformation was observed at the initial impact point. A-significant burnish mark and flattening was found on the stem at the bend. The appearance of folded metal was visible on the ID of the bend. The laser hole was seen at mid stem and pinch weld showed no damage. Neither influenced the bending of the stem. The bend angle was found to be $44^{\circ}$ as measured from the cone.

Metallographic Analysis [Attachment 5]:

Wall thinning was observed in the outside diameter of the bend as compared to the undamaged material. A lap was visible of the cross section at the ID of the bend; distinguishable by the heavy metal flow parallel to the defect. Small laps were also evident in the region.

\begin{tabular}{|c|c|c|c|c|c|}
\hline Test 6 & Serial & Condition & Stem & Drop & Load \\
& Number & & Angle & Height & Date \\
& 18557 & Aged & $70^{\circ}$ & $6^{\prime} 6^{\prime \prime}$ & $3 / 1 / 89$ \\
\hline
\end{tabular}

Video Tape Evaluation [Video ID\#9]:

The stem impacted first, bending into a " $L$ " shape at the cone. After the initial contact, the cone and the bottle followed. The nut did not contact the impact surface.

Visual Macro Exam [See Attachment 6]:

Metal deformation was observed at the initial impact point. A significant burnish mark and flattening was found on the stem at the bend. The metal fold appeared on the ID of the bend. 
The laser hole was seen at mid stem and pinch weld showed no damage. Neither influenced the bending of the stem. The stem bent to such a severe angle as to nearly contact both the nut and bottle. The bend angle was found to be $33^{\circ}$ as measured from the cone.

Metallographic Analysis [See Attachment 6]:

Wall thinning was observed in the outside diameter of the bend as compared to the undamaged material. A large lap was visible of the cross section at the ID of the bend and smaller laps were also evident in the region. The bend severely restricted the passage in the stem.

\begin{tabular}{|c|c|c|c|c|c|}
\hline Test 7 & $\begin{array}{c}\text { Serial } \\
\text { Number }\end{array}$ & Condition & $\begin{array}{c}\text { Stem } \\
\text { Angle }\end{array}$ & $\begin{array}{c}\text { Drop } \\
\text { Height }\end{array}$ & $\begin{array}{c}\text { Load } \\
\text { Date } \\
\end{array}$ \\
4818 & Aged & $88^{\circ}$ & $6^{\prime} 6^{\prime \prime}$ & $6 / 1 / 79$ \\
\hline
\end{tabular}

Video Tape Evaluation [Video ID\#10]:

The stem impacted first, bending into a " $\mathrm{l}$ " shape at mid stem and a " $\mathrm{L}$ " shape at the cone. The two bend were in differing planes approximately $90^{\circ}$ from each other. After the initial contact, the cone and the bottle followed. The nut did not contact the impact surface.

Visual Macro Exam [See Attachment 7]:

Metal deformation was observed at the initial impact point. A burnish mark and slight flattening was found on the stem at the "L" bend. No burnish mark was seen on the "J" bend. The two laser holes were seen just above the cone and did not appear to influence the bending of the stem. The pinch weld showed no damage and did not influence the bending of the stem.

Metallographic Analysis [See Attachment 7]:

Localized wall thinning was observed in the outside diameter of the bend at the as compared to the undamaged material. Laps were visible of the cross section at the ID of the bend at the cone. Wall thinning was evident in the " $J$ " bend and the ID region was free of laps.

\begin{tabular}{|c|c|c|c|c|c|}
\hline Test 8 & $\begin{array}{c}\text { Serial } \\
\text { Number }\end{array}$ & Condition & $\begin{array}{c}\text { Stem } \\
\text { Angle }\end{array}$ & $\begin{array}{c}\text { Drop } \\
\text { Height }\end{array}$ & $\begin{array}{c}\text { Load } \\
\text { Date }\end{array}$ \\
& 4025 & Aged & $88^{\circ}$ & $6^{\prime} 6^{\prime \prime}$ & $8 / 1 / 79$ \\
\hline
\end{tabular}

Video Tape Evaluation [Video ID \#11]:

The stem impacted first. The type of bending could not be observed from the camera angle.

After impact the bottle rolled in the plane of the camera, obscuring the view. The stem, however, bend into a " $S$ " shape with bending at mid stem and at the cone. After the initial contact, the cone followed by the nut contacted the impact surface. The bottle impact could not be observed.

\section{Visual Macro Exam [See Attachment 8]:}

Metal deformation was observed at the initial impact point and a slight burnish mark was found on the stem at the bend near the cone. The laser hole was seen just above the cone and the pinch weld appeared undamaged. Neither influenced the bending of the stem. The bent stem was severe, with the bent stem nearly bending back unto itself.

Metallographic Analysis [See Attachment 8]:

Wall thinning was observed in the outside diameter at the mid stem bend and the cone region as compared to the undamaged material. Numerous small laps were seen. 


\begin{tabular}{|c|c|c|c|c|c|}
\hline Test 9 & $\begin{array}{c}\text { Serial } \\
\text { Number }\end{array}$ & Condition & $\begin{array}{c}\text { Stem } \\
\text { Angle }\end{array}$ & $\begin{array}{c}\text { Drop } \\
\text { Height }\end{array}$ & $\begin{array}{c}\text { Load } \\
\text { Date } \\
\end{array}$ \\
$23350 \mathrm{~A}$ & Unaged & $70^{\circ}$ & $6^{\prime} 6^{\prime \prime}$ & NA \\
\hline
\end{tabular}

Video Tape Evaluation [Video ID\#12]:

The stem impacted first, bending into a " $L$ " shape at the cone. After the initial contact, the cone and the bottle followed. The nut did not contact the impact surface.

Visual Macro Exam [See Attachment 9]:

Metal deformation was observed at the initial impact point. A significant burnish mark, flattening, and folded metal were found on the stem at the bend. The stem bent to such a severe angle as to nearly contact both the nut and bottle. This test sample was conducted with an unaged unit and contained no laser hole or pinch weld. The bend angle was found to be $39^{\circ}$ as measured from the cone.

Metallographic Analysis [See Attachment 9]:

Wall thinning and flattening was observed in the outside diameter of the bend and a large lap was visible of the cross section at the ID of the bend. Smaller laps were also evident in the region. The bend severely restricted the passage in the stem.

\begin{tabular}{|c|c|c|c|c|c|}
\hline Test 10 & $\begin{array}{c}\text { Serial } \\
\text { Number } \\
25826 \mathrm{~A}\end{array}$ & $\begin{array}{l}\text { Condition } \\
\text { Unaged }\end{array}$ & $\begin{array}{c}\text { Stem } \\
\text { Angle } \\
88^{\circ}\end{array}$ & $\begin{array}{c}\text { Drop } \\
\text { Height } \\
6^{\prime} 6^{\prime \prime}\end{array}$ & $\begin{array}{c}\text { Load } \\
\text { Date } \\
\text { NA }\end{array}$ \\
\hline
\end{tabular}

Video Tape Evaluation [Video ID \#13]:

The stem impacted first, bending into a " $S$ " shape with bending at mid stem and the cone. After the initial contact, the cone and bottle impact followed with no impact to the nut.

\section{Visual Macro Exam:}

Metal deformation was observed at the initial impact point. A burnish mark and slight flattening was found on the stem at the bend near the cone. The bend near mid stem was severe with the stem nearer bend back upon itself. This test sample was conducted with an unaged unit and contained no laser hole or pinch weld.

Metallographic Analysis:

Wall thinning was observed in the outside diameter of both bends. Small laps were visible in the cross section at the ID of the bends.

\section{Conclusions}

The results showed both the aged and unaged units bent essentially as anticipated. Similar bend results were exhibited when comparing aged test results (Test $5 \& 6$ and $7 \& 8$ ) with unaged units (Test 9 and 10). This suggests minimal, if any, degradation due to the tritium exposure and the aging process.

A comparison between the SRTC testing and the drop testing conducted at SNL-CA indicated agreement with the results. This agreement also supports the assessment that the tritium exposure and the aging process have minimal effect on influencing the bending action under a dropping scenario. 


\section{References}

1. WSRC-RP-99-00220, "PRELIMINARY REPORT: DROP TESTING OF AGED STEMS ON THE SP981 RESERVOIR", by M. B. White, February 17, 1999.

2. Sandia National Laboratories Report, "Drop Tests of Unaged Reservoirs", by S. L. Robinson \& G. C. Cook, April 6, 1998.

\section{Acknowledgments}

Sarah Rhodes and Neta Rutland (Chemical \& Hydrogen Technology Section, Savannah River Technology Center) conducted the metallography presented in this report in the Materials Test Facility, Building 232- $\mathrm{H}$. 


\section{ATTACHMENT 1}

\section{METALlogRAPHY OF BENT STEM FROM SP981 / 4874; AGED RESERVOIR}

Test 1

$981 / 4874$

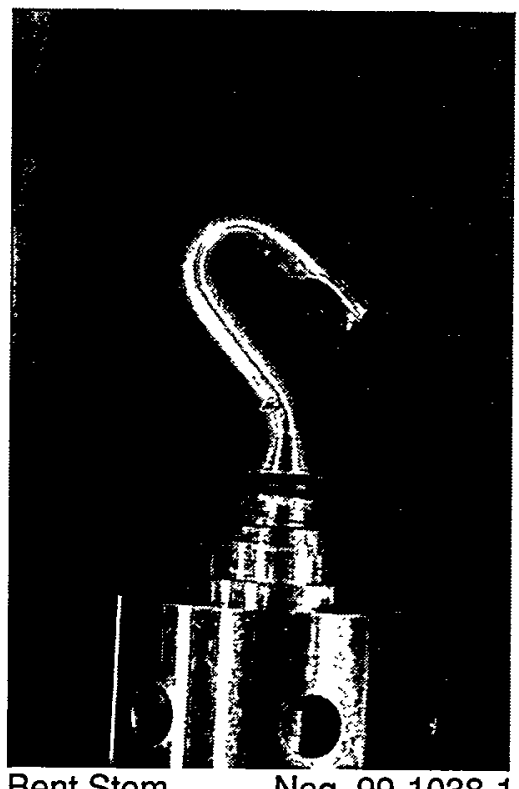

Bent Stem

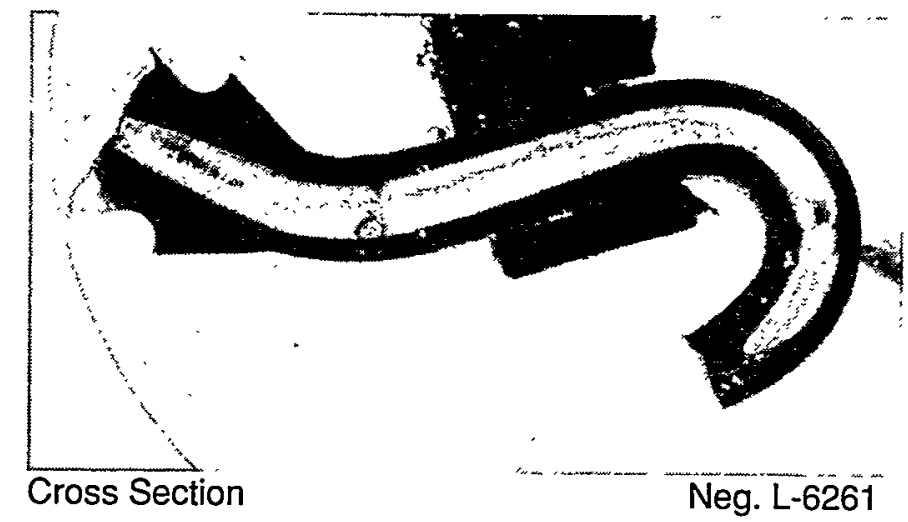

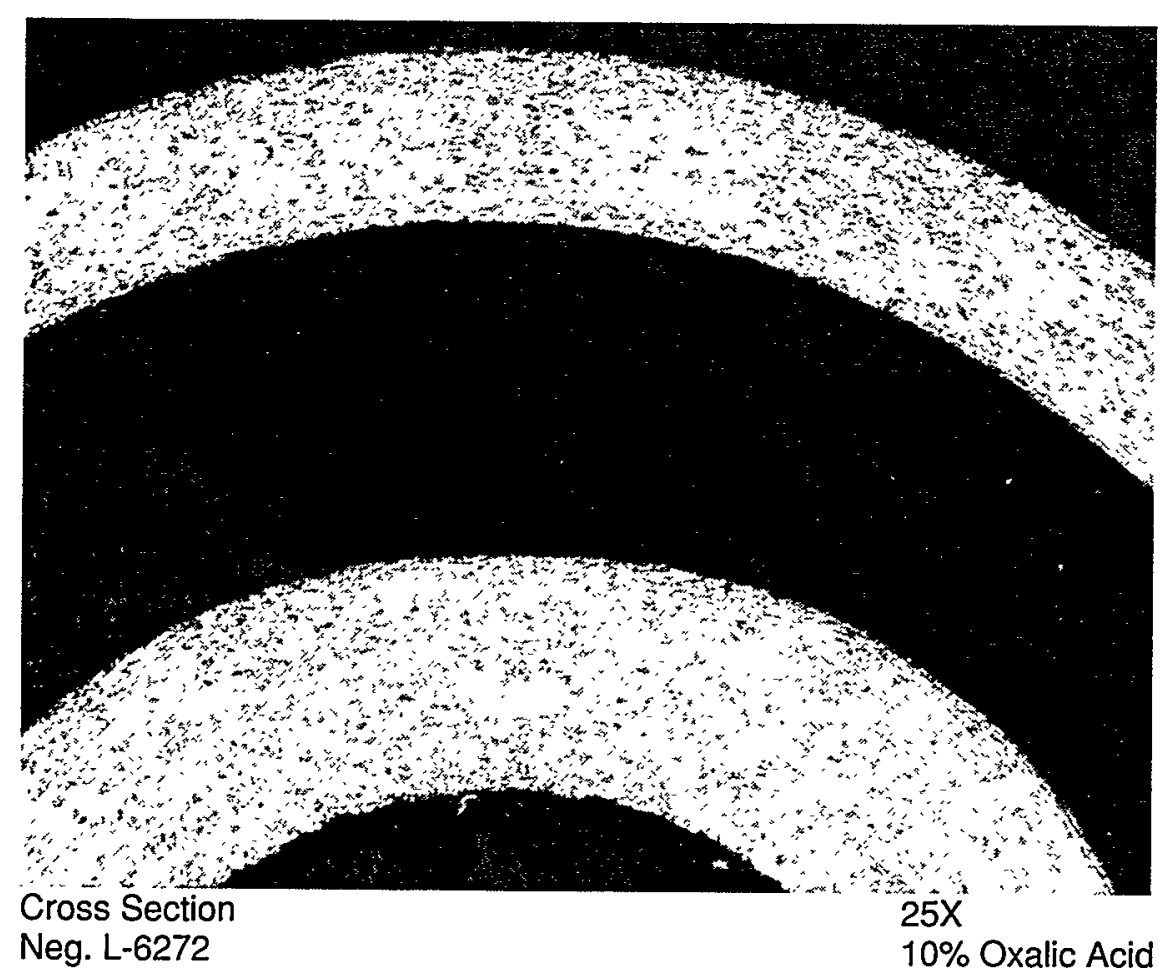


Test 2

$981 / 4863$

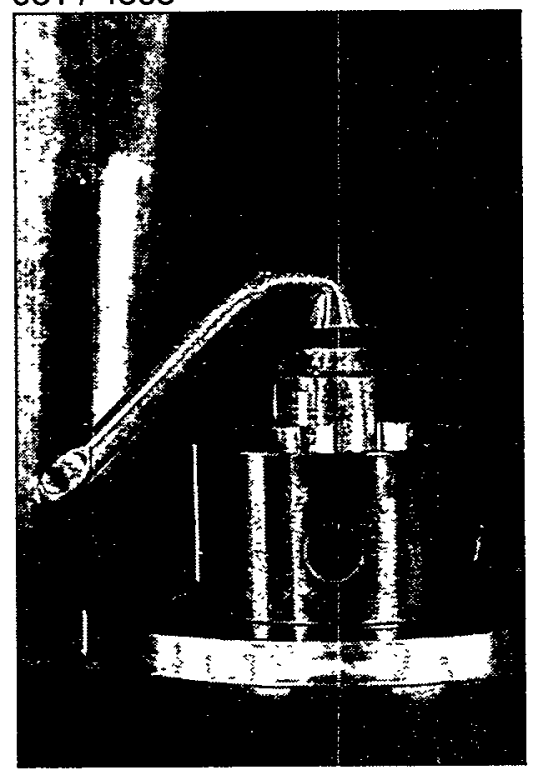

Bent Stem

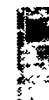
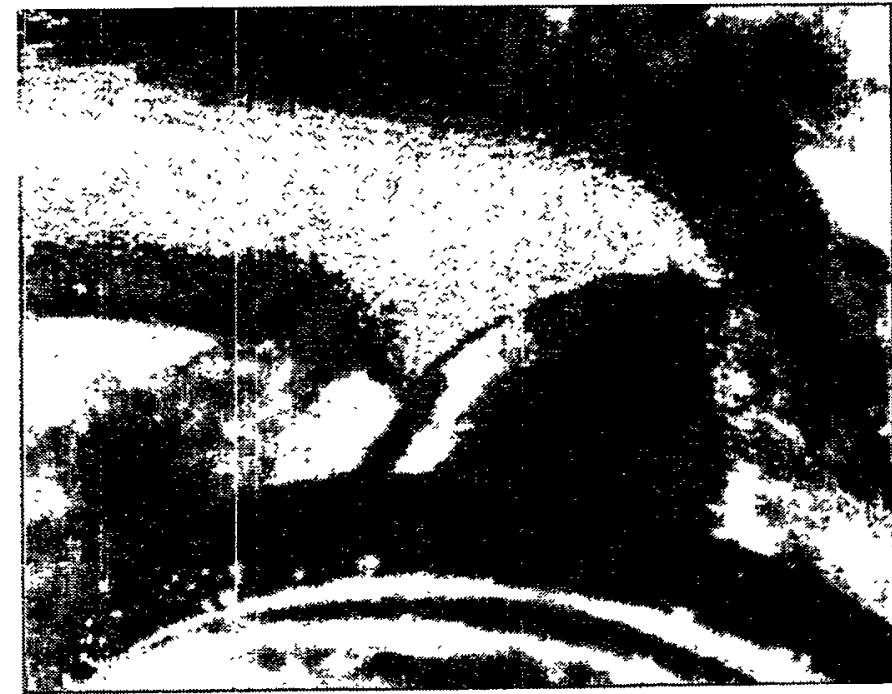

View of the lap beneath the bend Neg. L-6170

Page 1 of 2

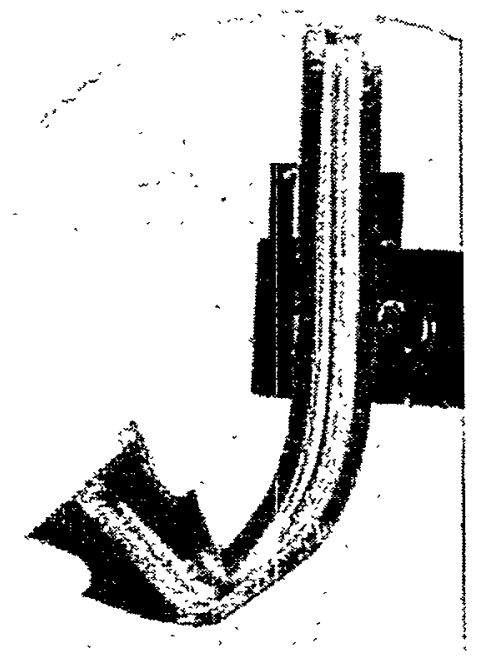

Cross Section

Neg. L-6262 
WSRC-TR-99-00144

Test 2

Attachment 2 continued

$981 / 4863$

Page 2 of 2
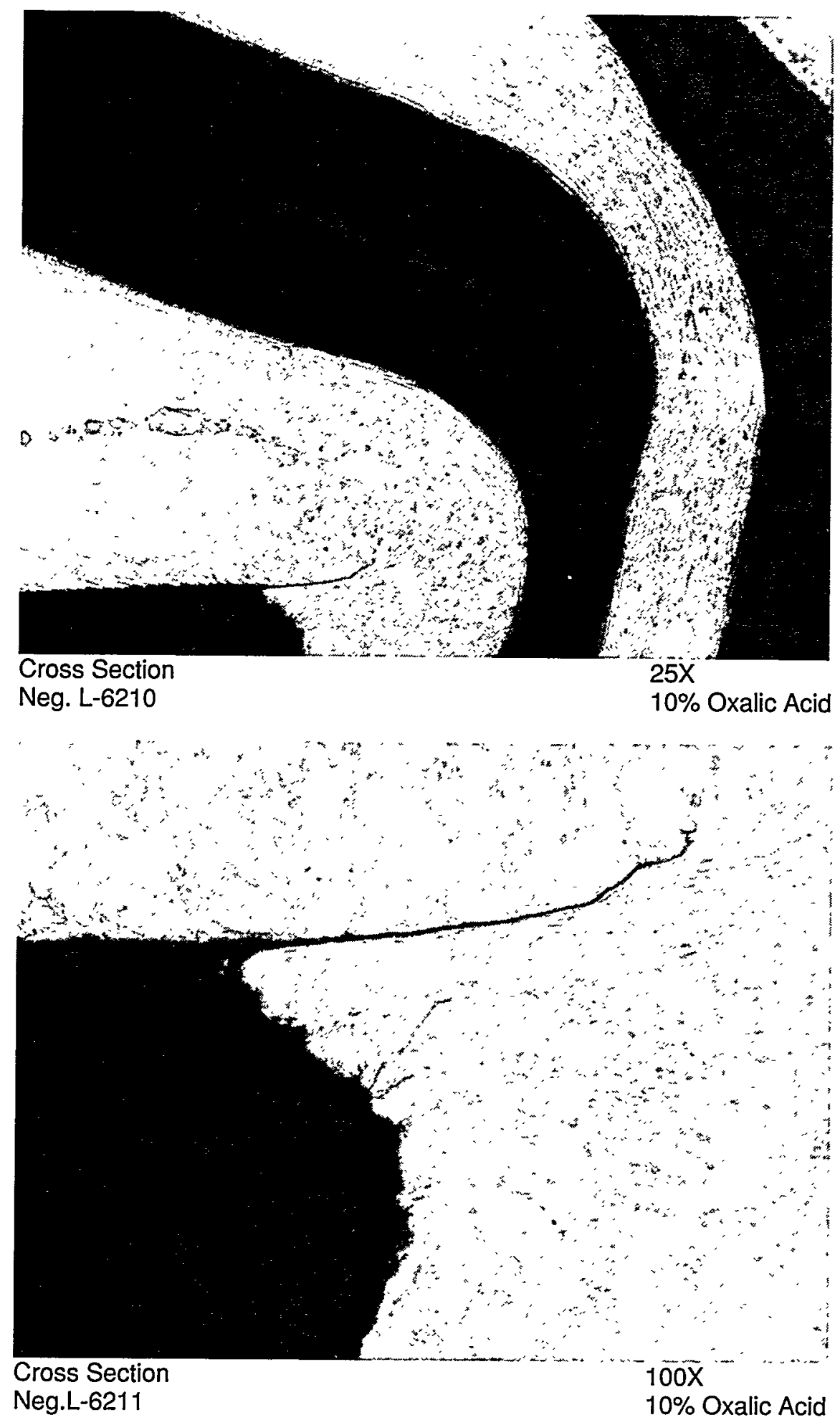
ATTACHMENT 3

Metallography of Bent Stem From SP981 / 16707; Aged Reservolr

Test 3

$981 / 16707$

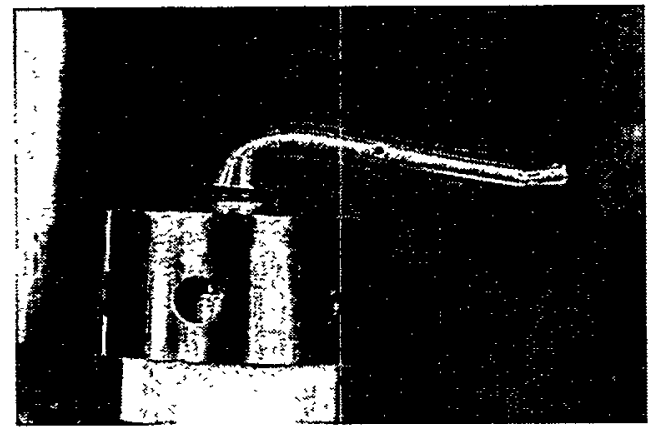

Bent Stem

Neg. 99-1038-6

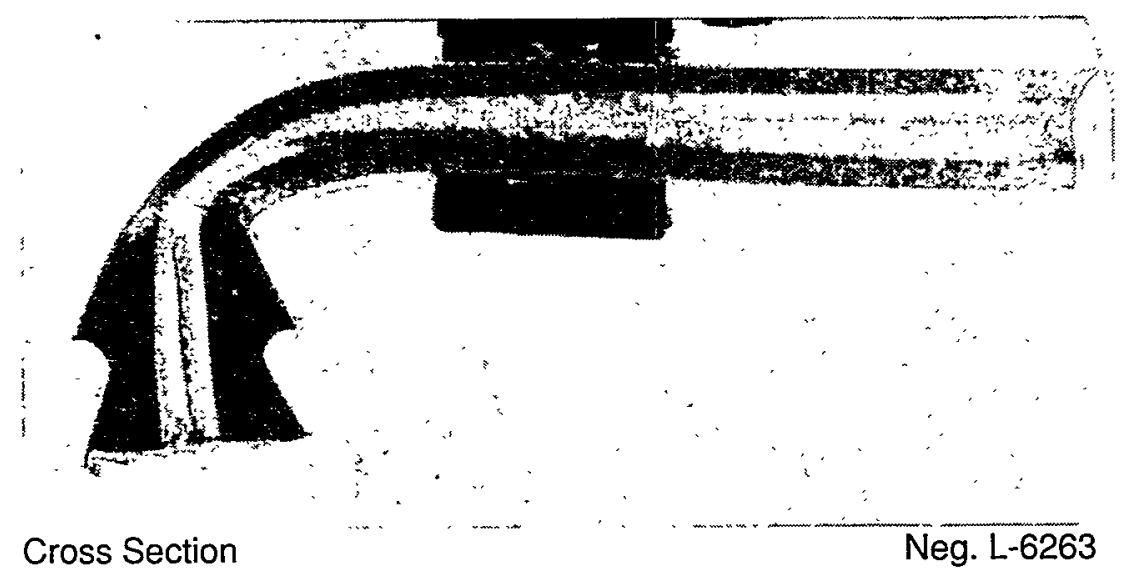


Test 3

\section{Attachment 3 continued}

\section{$981 / 16707$}

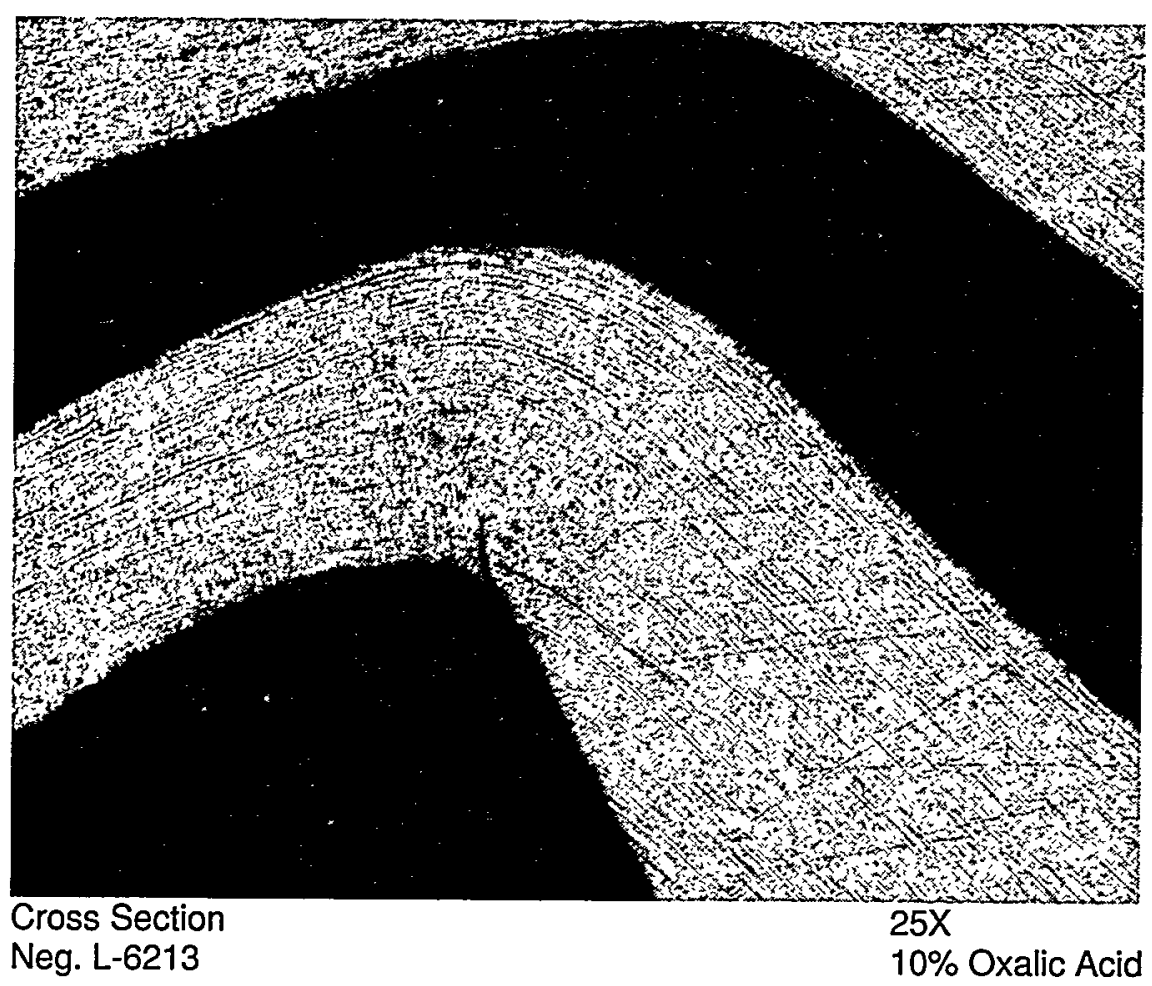

Page 2 of 2

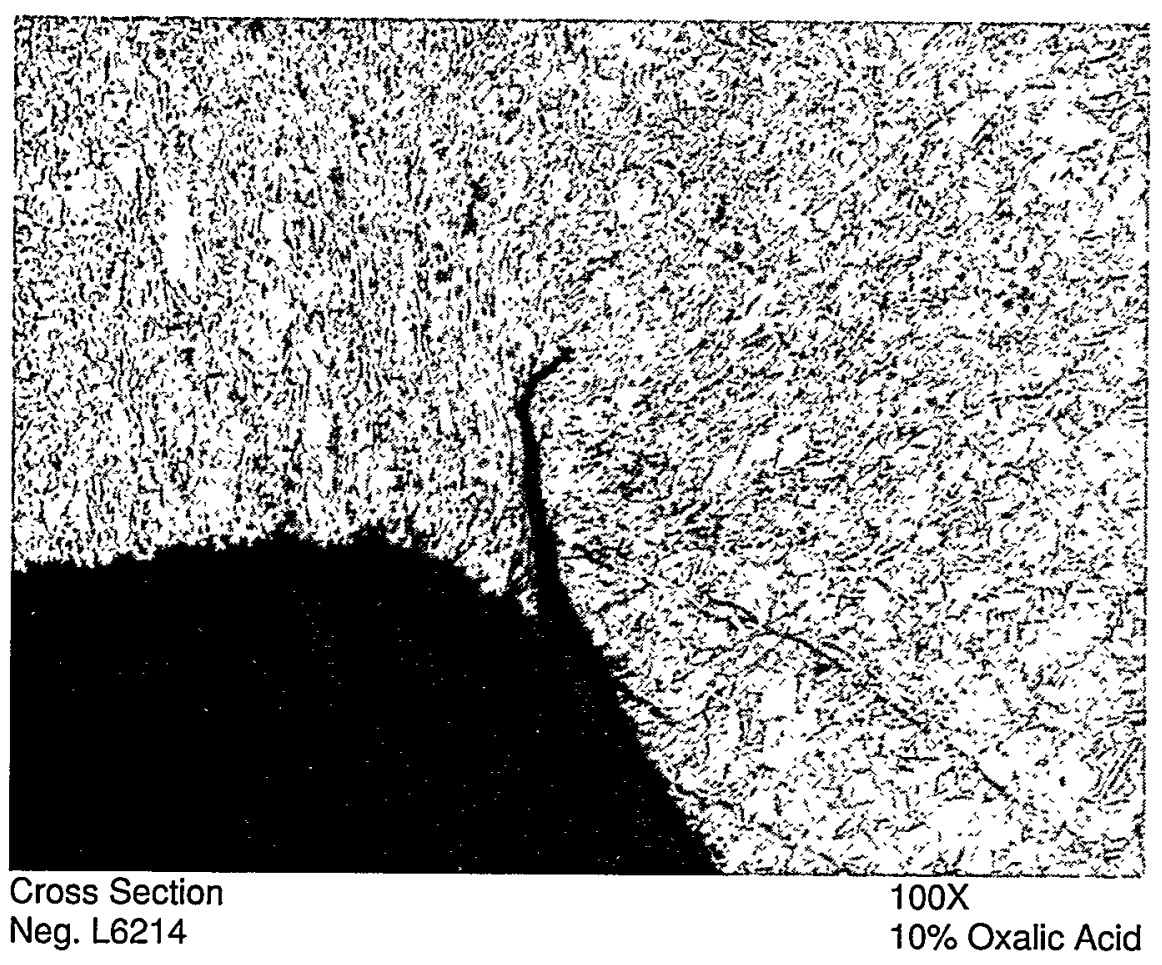


ATTACHMENT 4

Metallography of Bent Stem FROM SP981 / 4843; AGED RESERVOIR

Test 4

$981 / 4843$

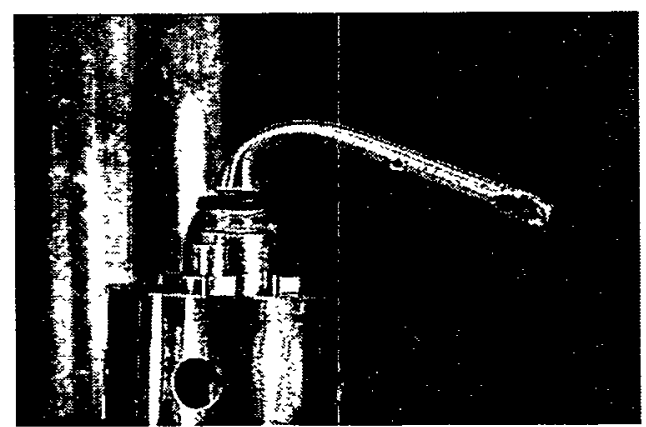

Bent Stem
Neg. 99-1038-8
Page 1 of 2

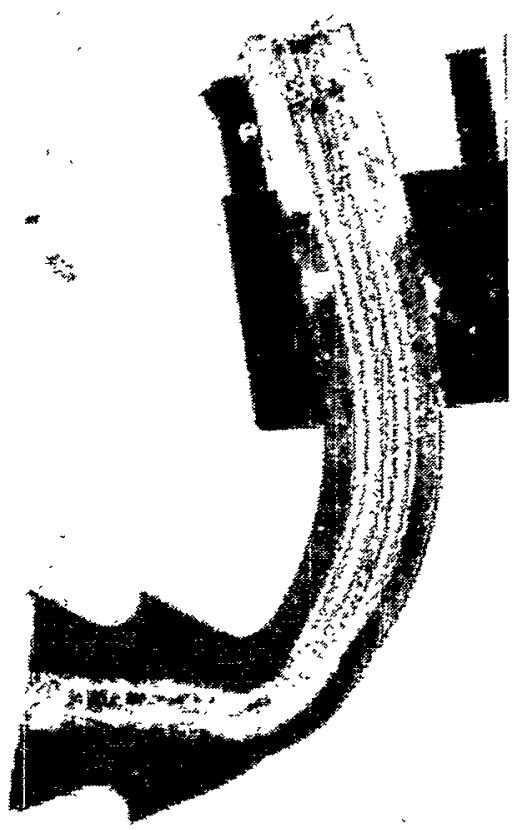

Cross Section

Neg. L-6264 
Test 4

$981 / 4843$
Attachment 4 continued

Page 2 of 2
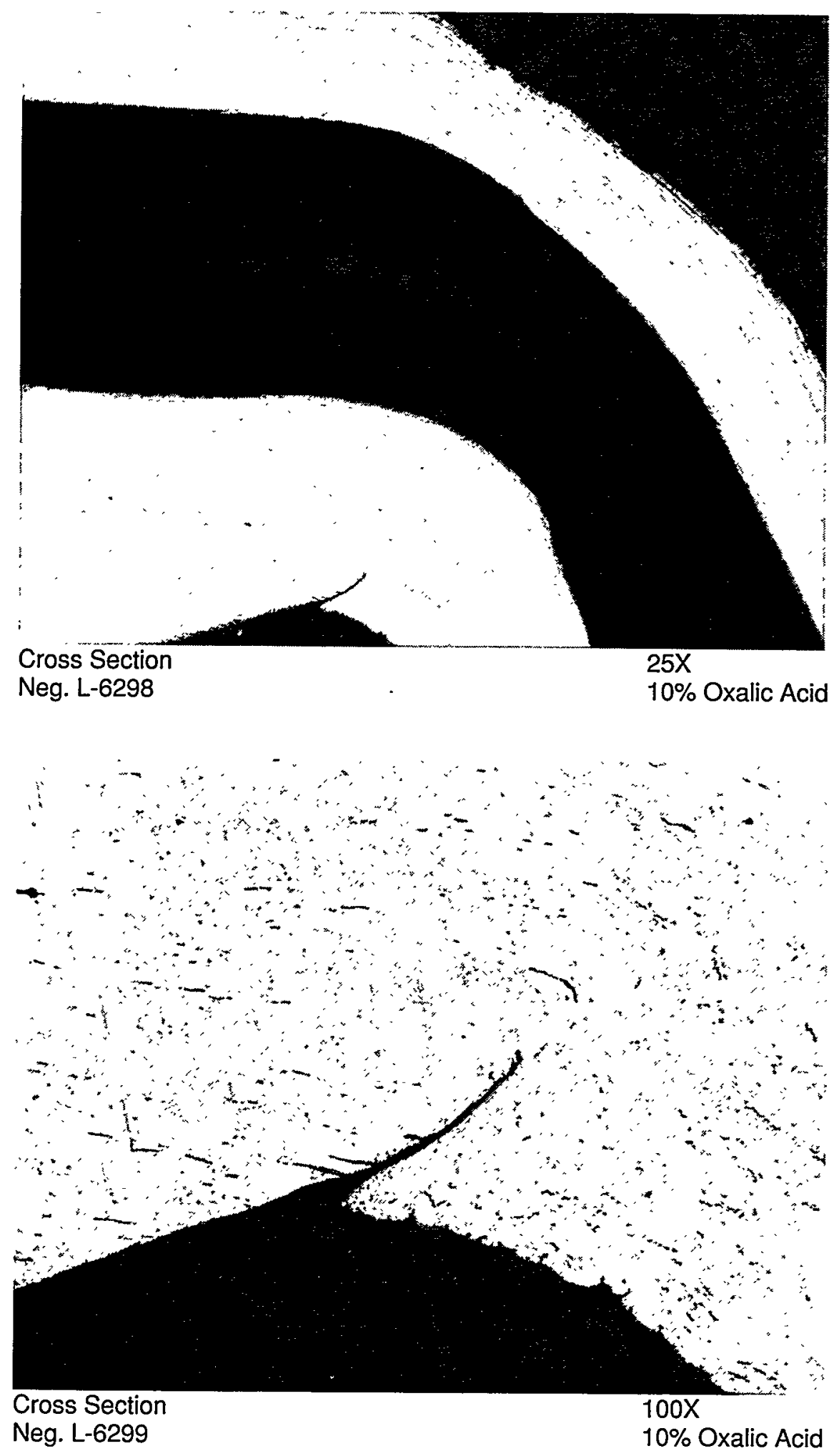
ATTACHMENT 5

Metallography of Bent Stem fRom SP981 / 4007; Aged RESERVOIR

Test 5

$981 / 4007$

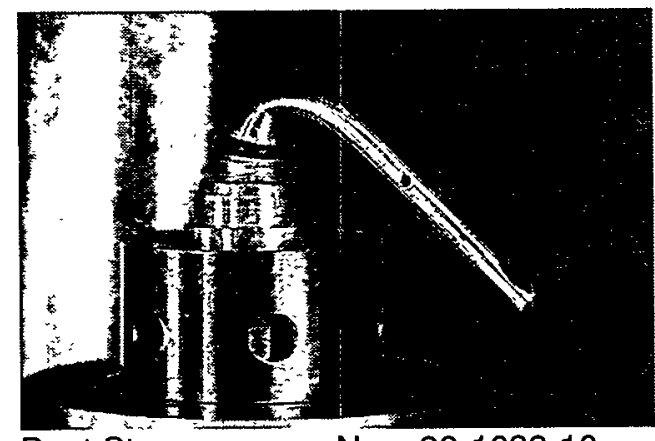

Neg. $99-1038-10$

Page 1 of 2

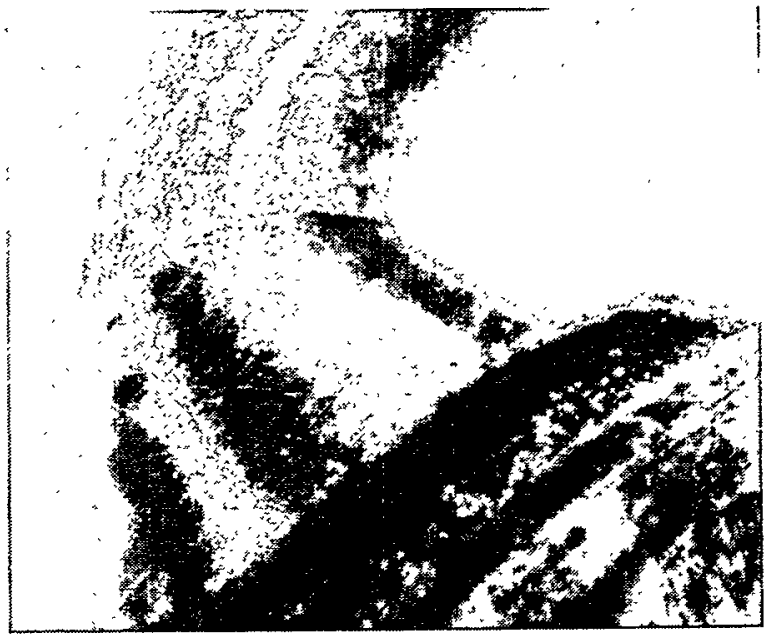

View of the lap beneath the bend Neg. L-6172

$16 X$

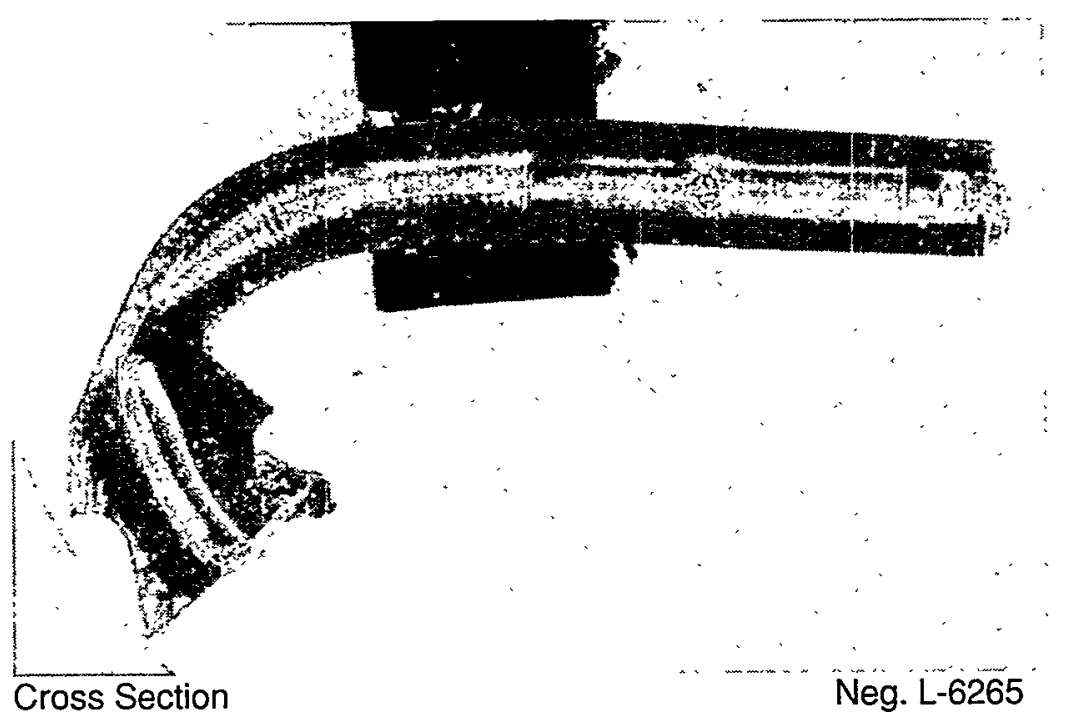


Test 5

$981 / 4007$

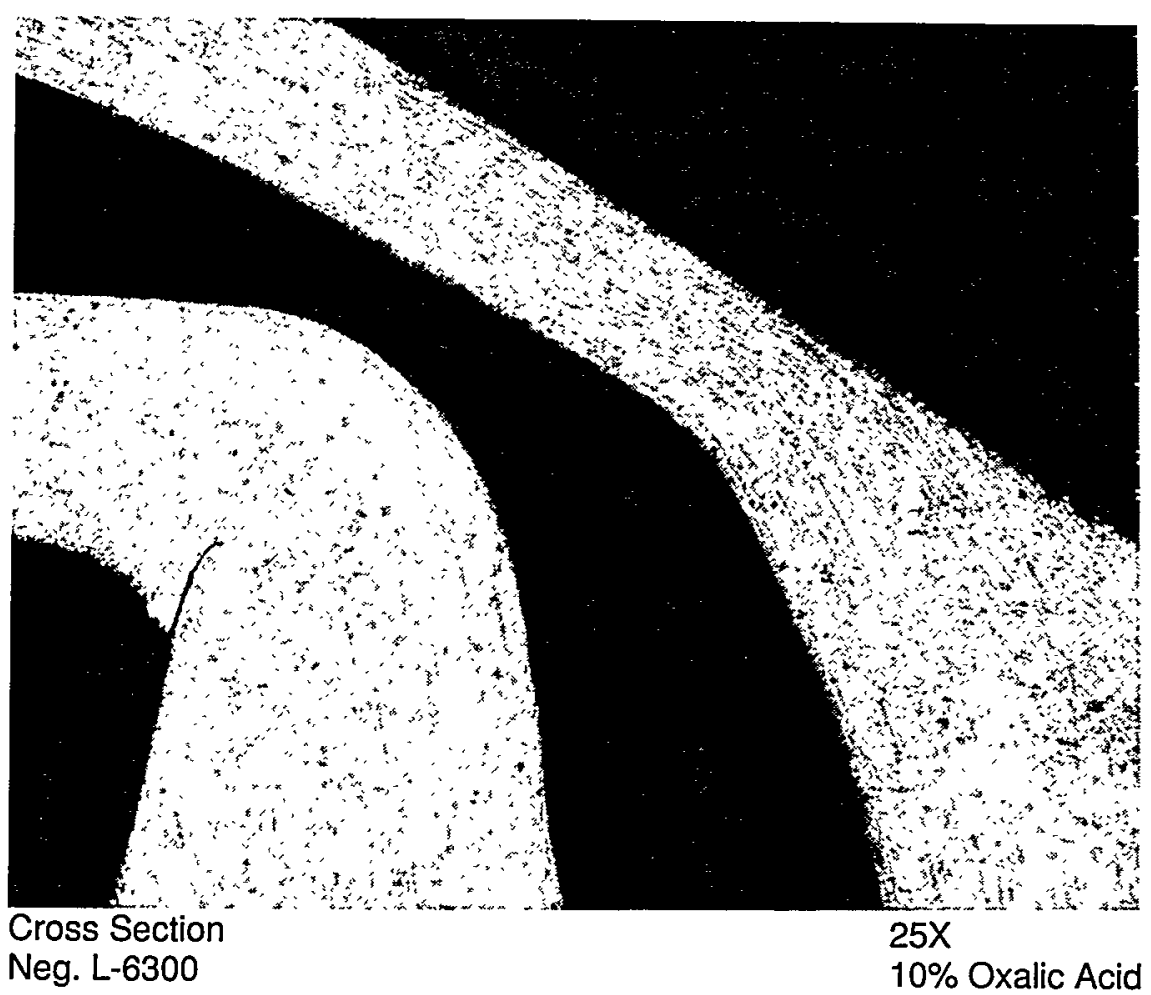

Page 2 of 2

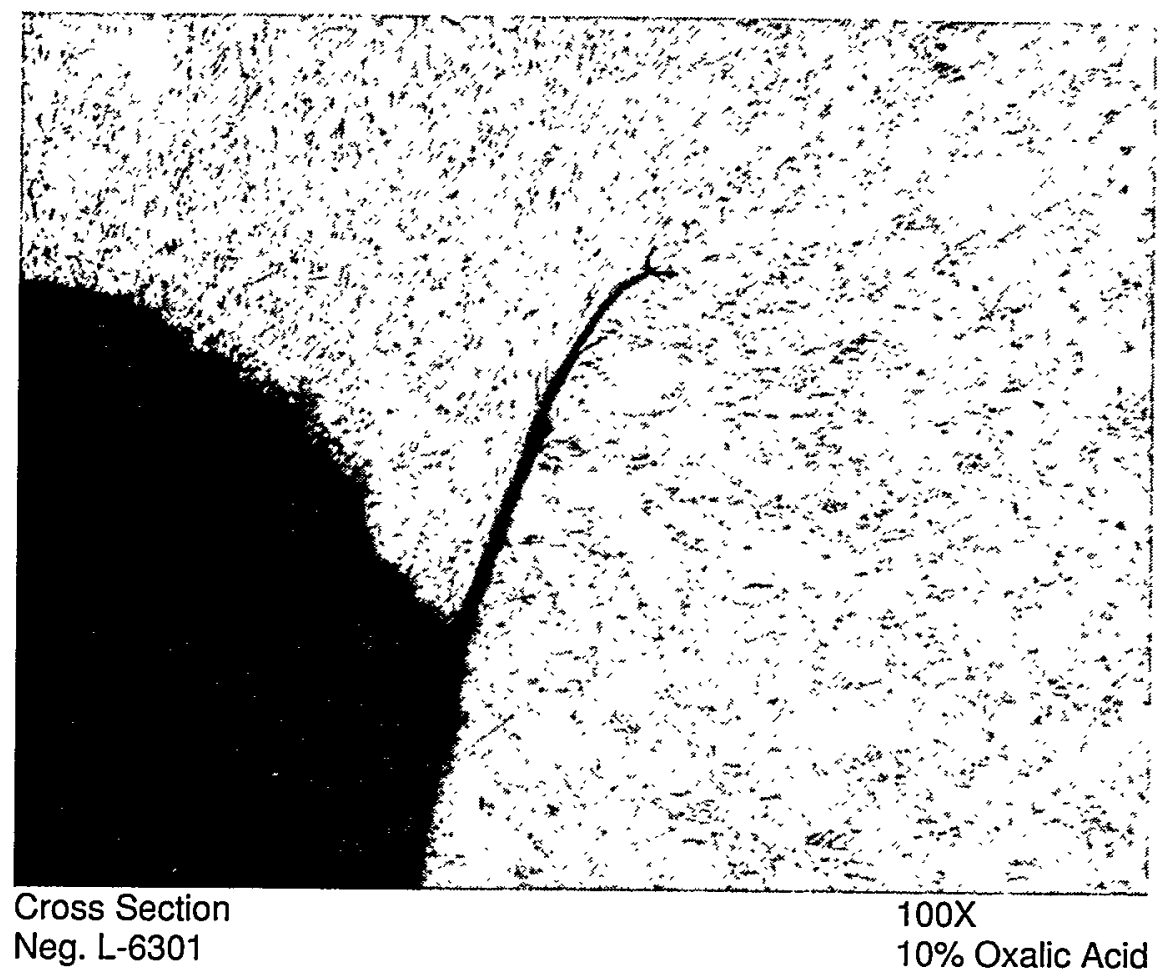


Test 6

$981 / 18557$

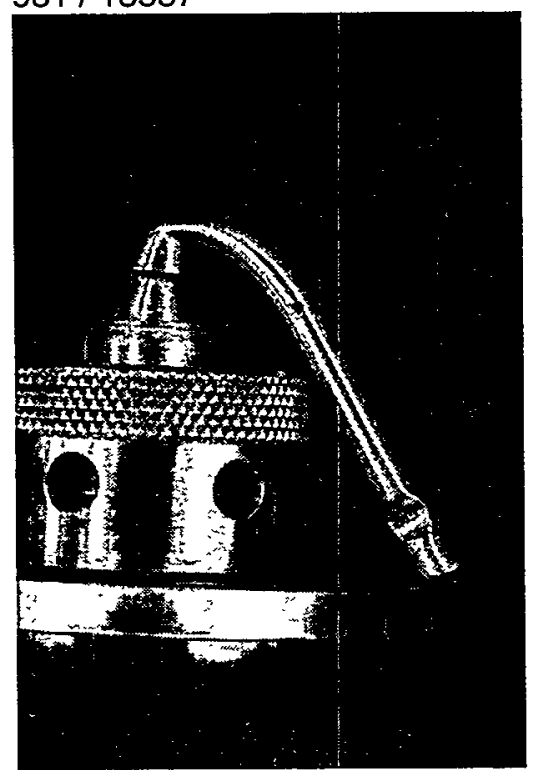

Bent Stem

Neg. $99-1038-12$

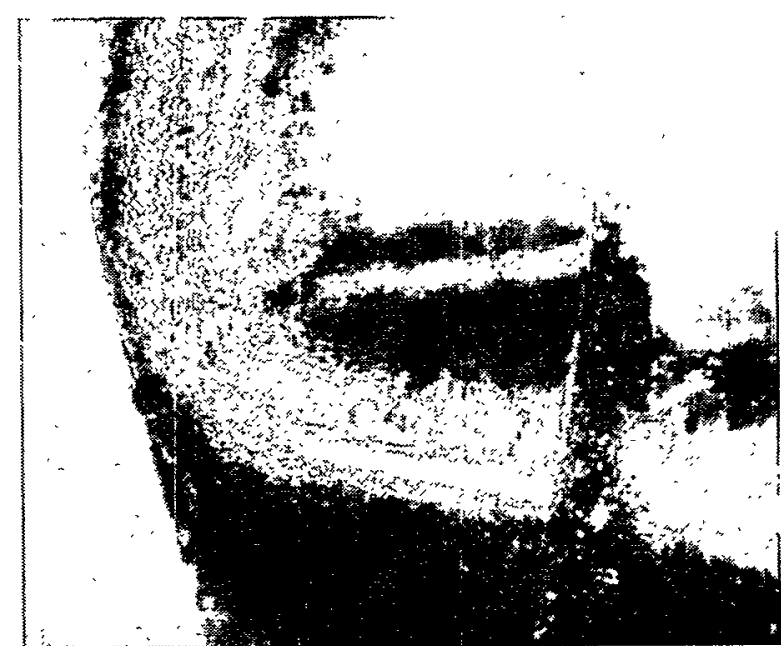

View of the lap beneath the bend Neg. L-6173

Page 1 of 2

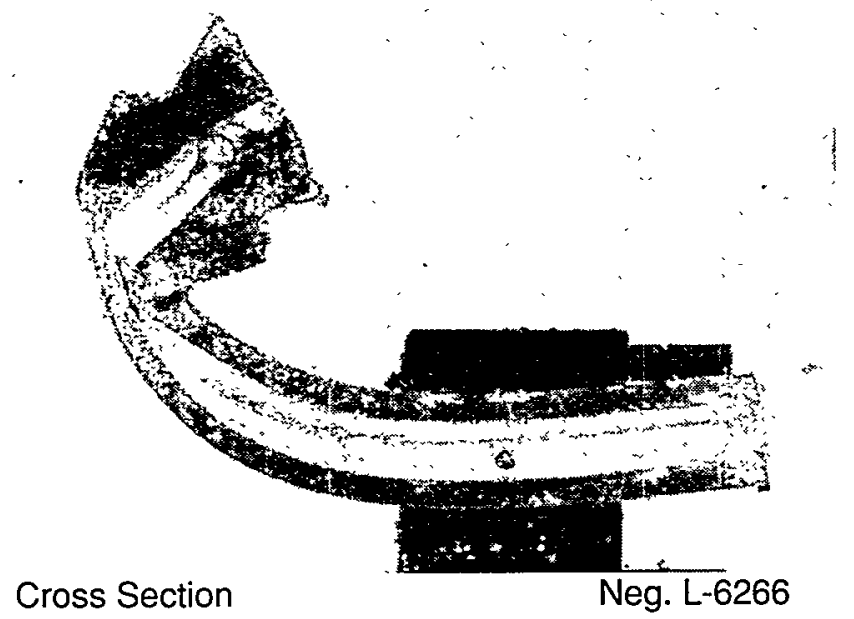


Test 6

$981 / 18557$

\section{Attachment 6 continued}

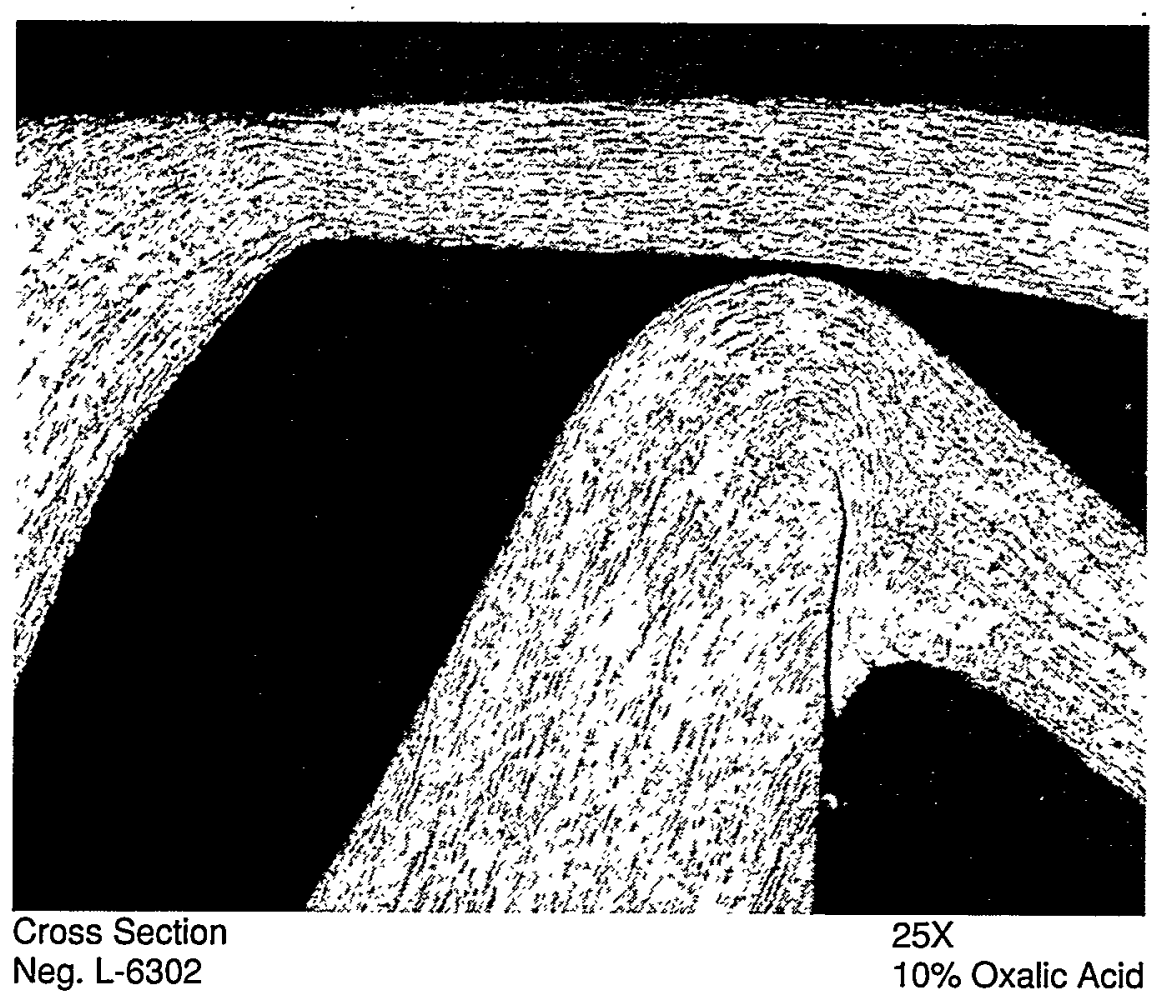

Page 2 of 2

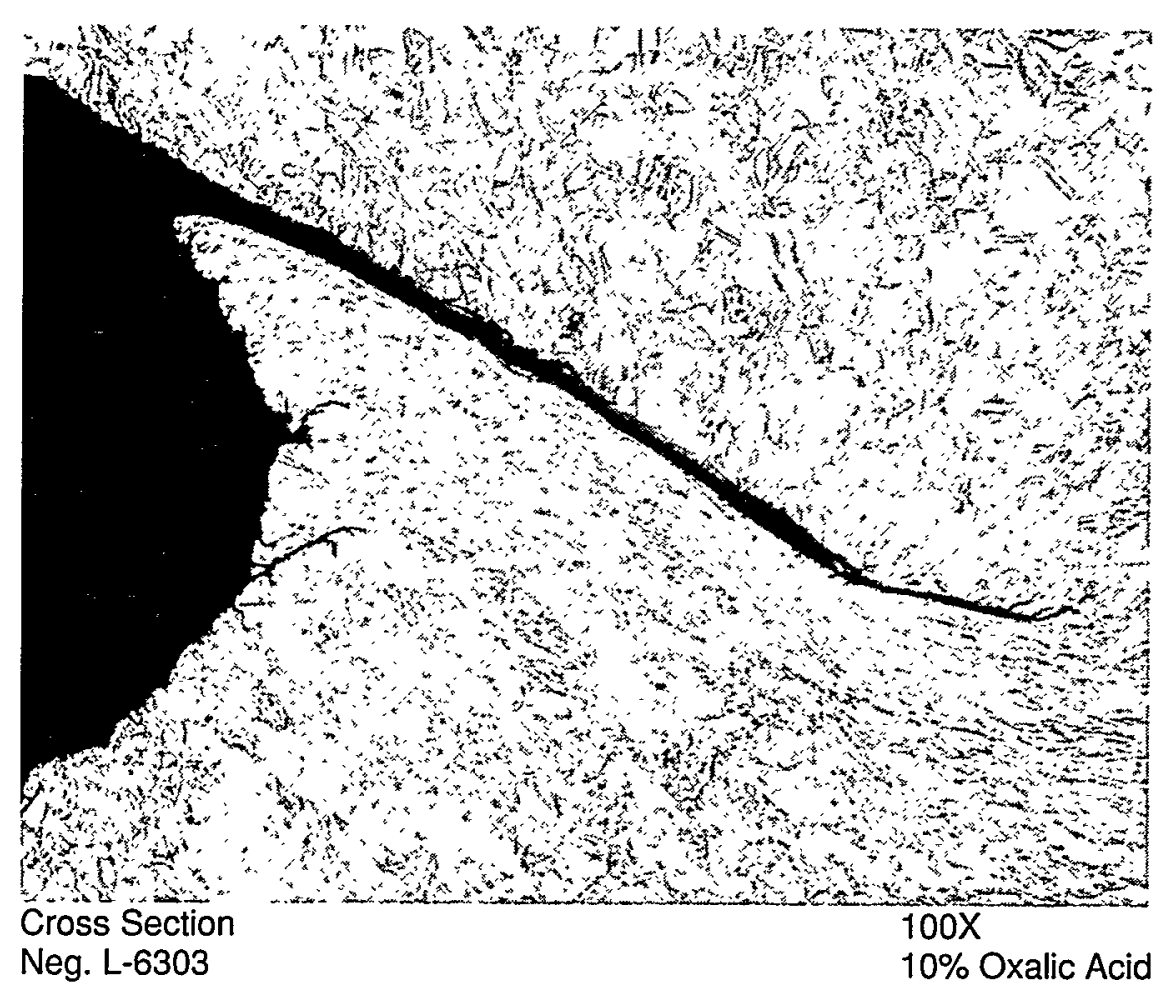




\section{ATTACHMENT 7}

METALLOGRAPHY OF BENT STEM FROM SP981 / 4818; AgEd RESERVOIR

Test 7

$981 / 4818$
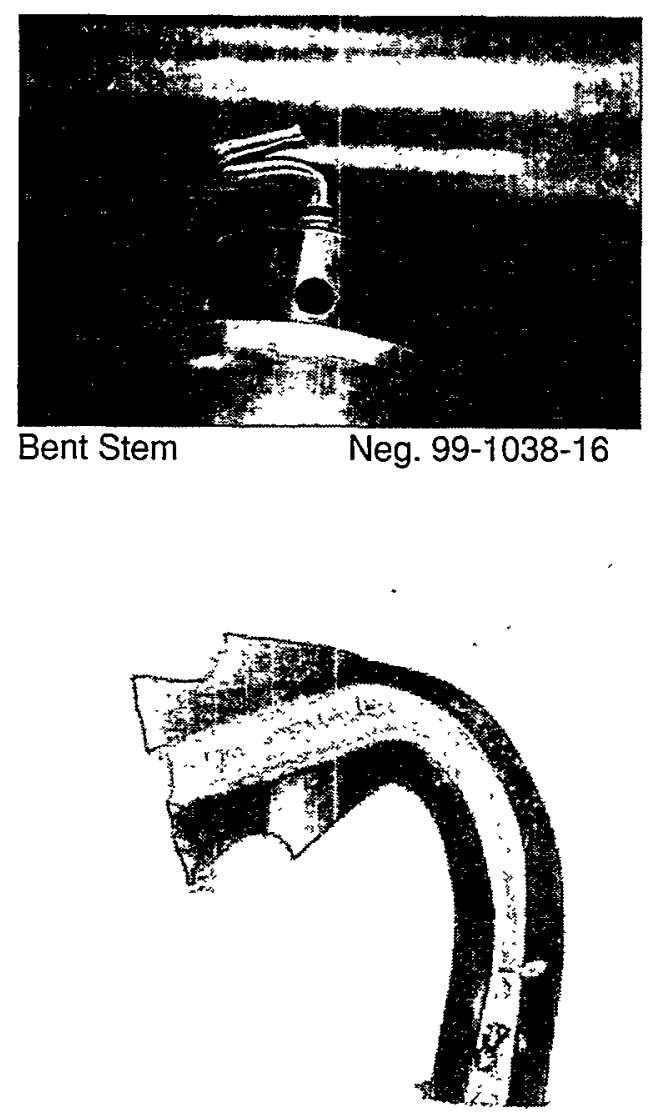

Cross Section at Cone

Neg. L-6267
Page 1 of 2

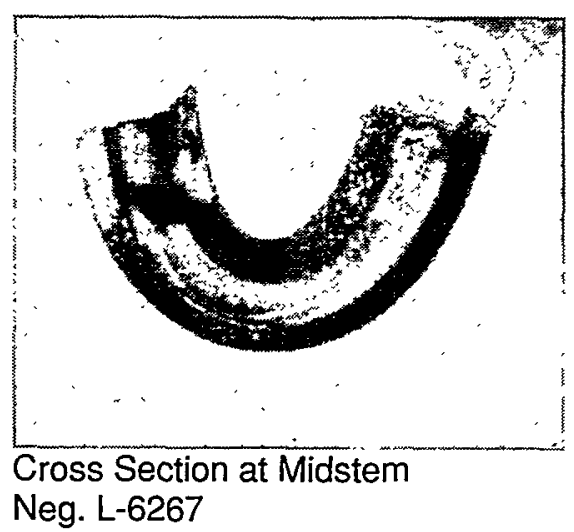


Test 7

$981 / 4818$

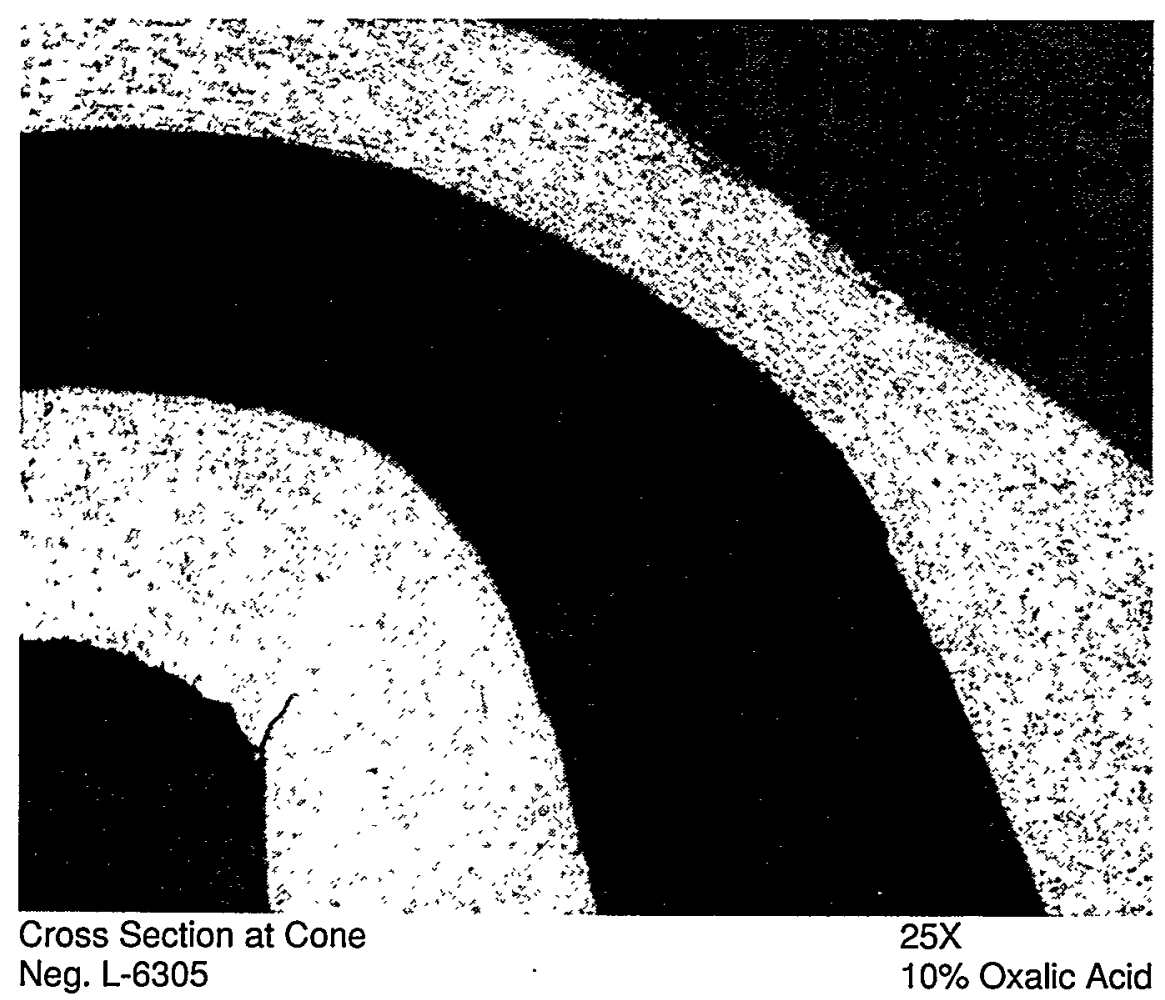

Page 2 of 3

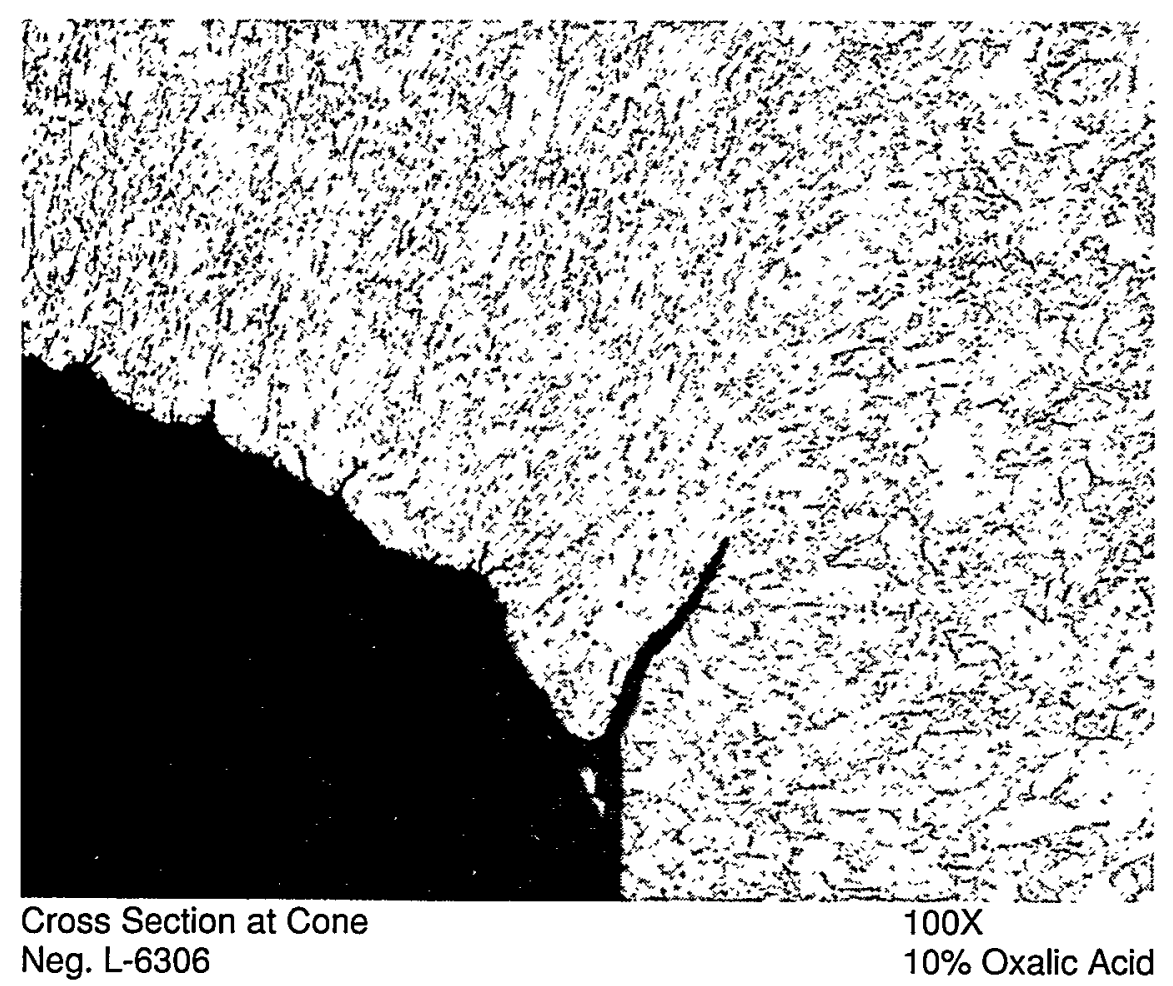


WSRC-TR-99-00144

Test 7

Attachment 7 continued

$981 / 4818$

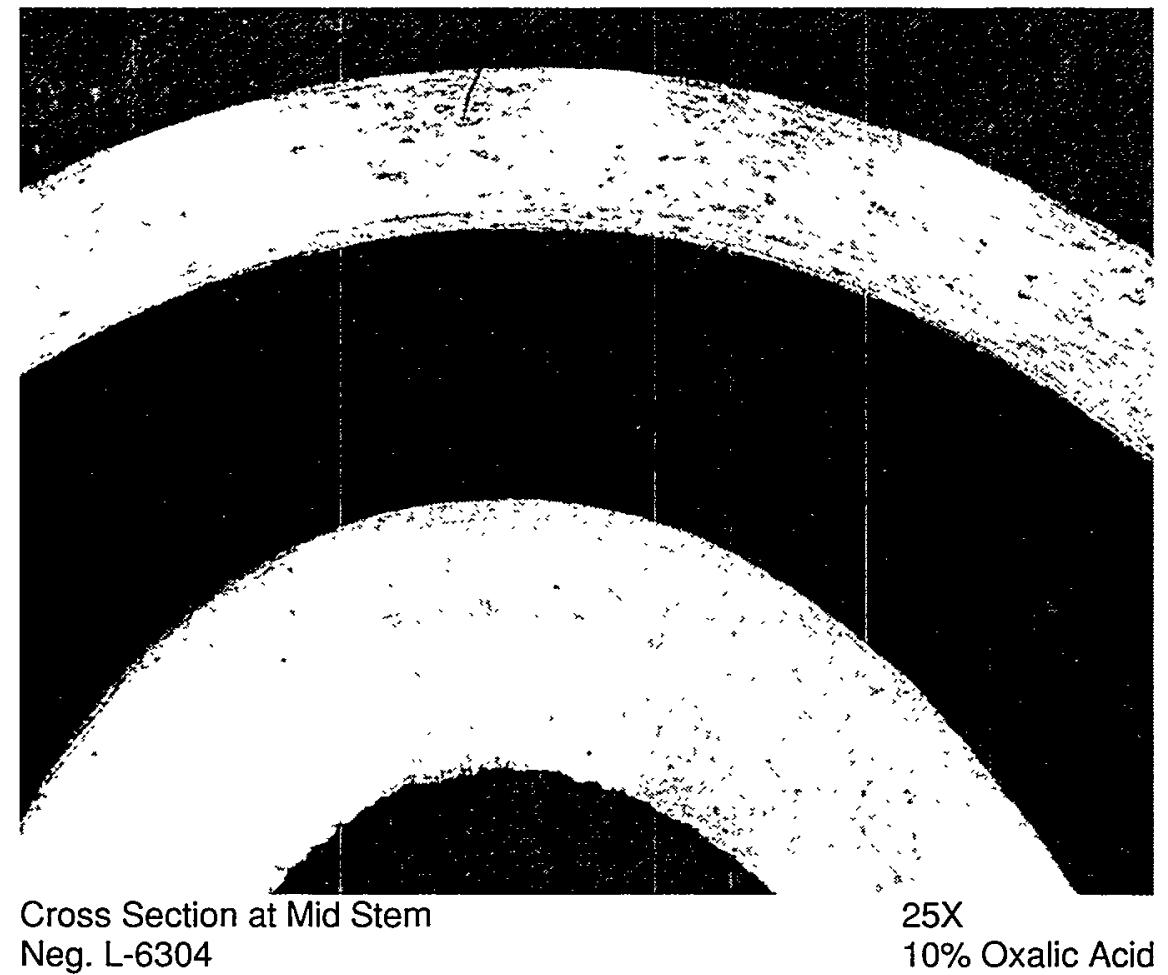




\section{ATTACHMENT 8}

METALLOGRAPHY OF BENT STEM FROM SP981 / 4025; AGED RESERVOIR

Test 8

$981 / 4025$

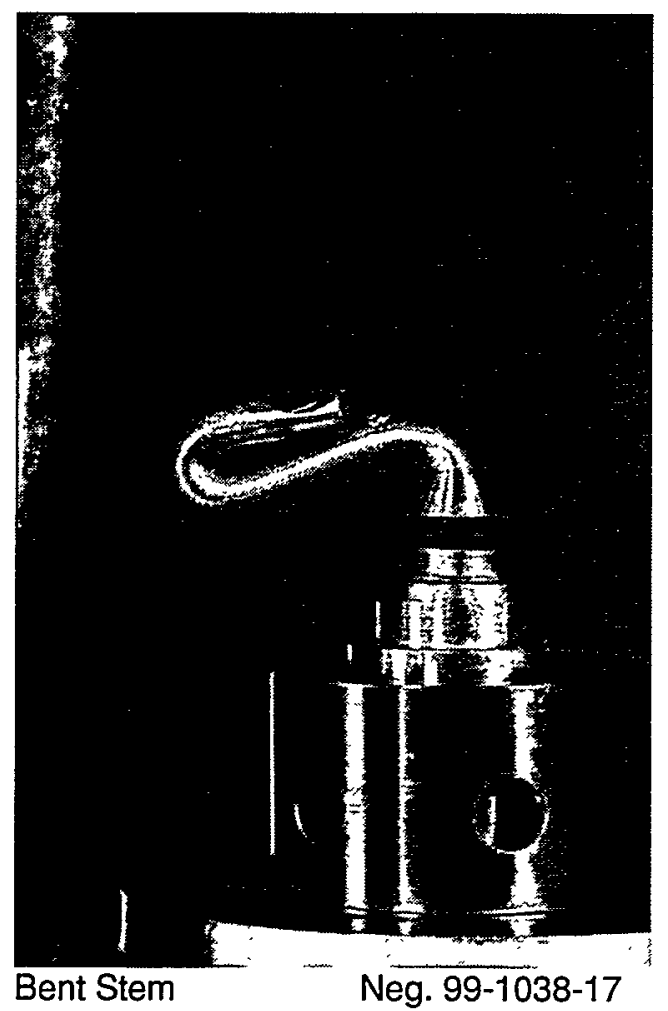

Page 1 of 2

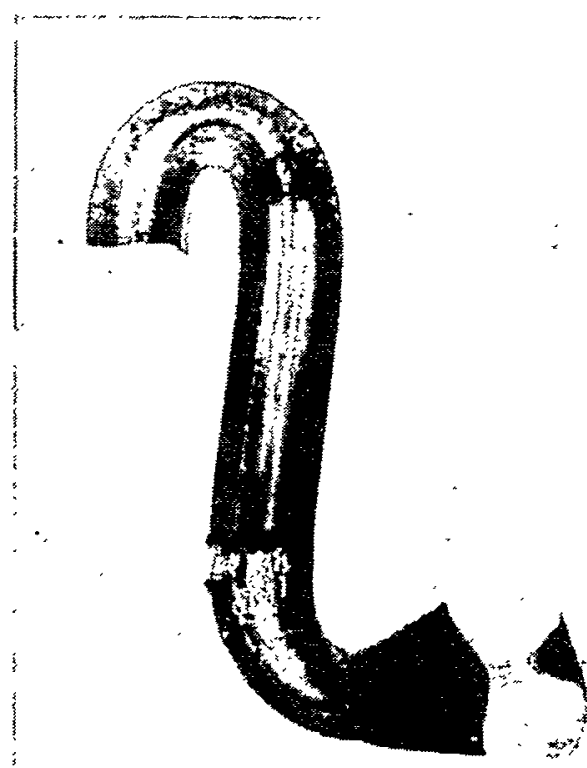

Cross Section at Mid Stem Neg. L-6268 
Test 8

$981 / 4025$
Attachment 8 continued

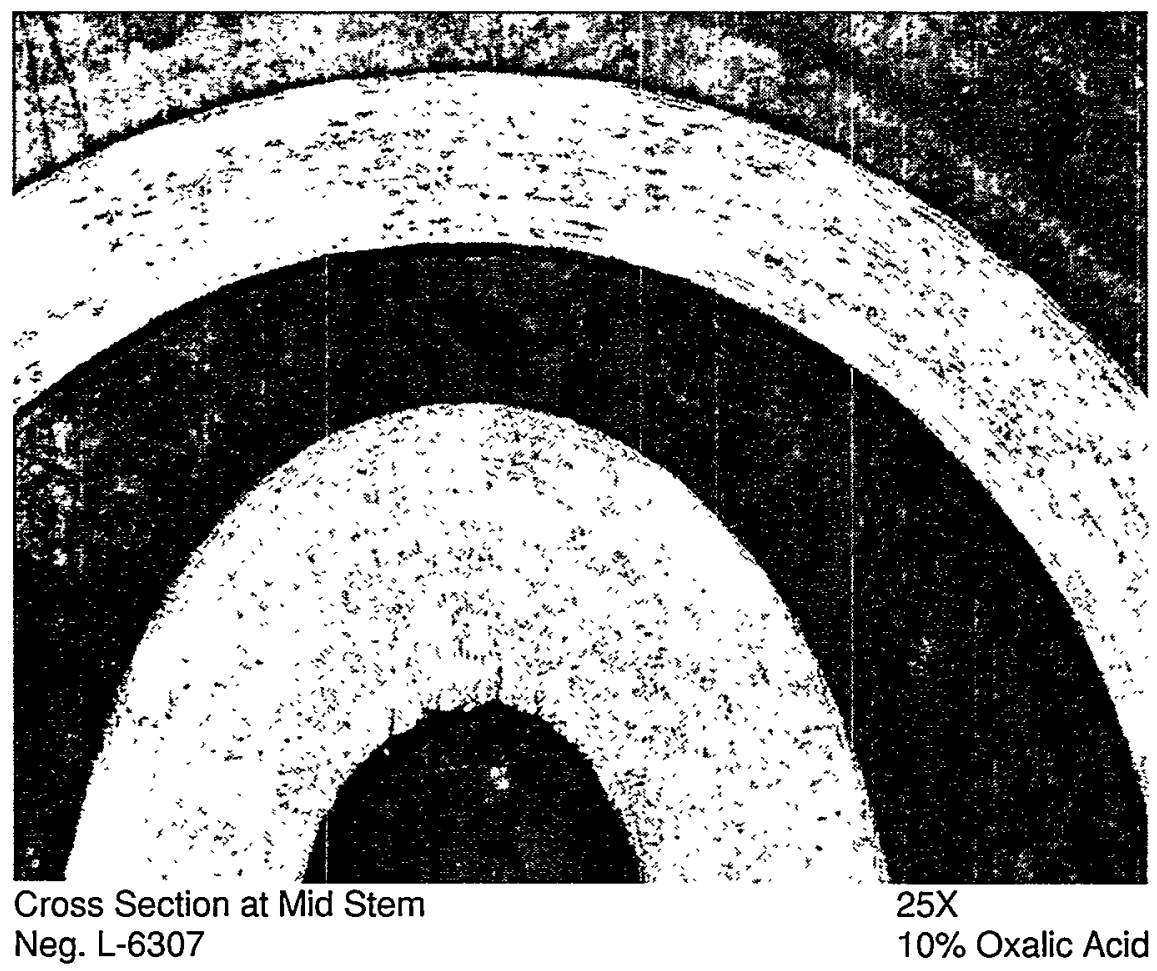

Page 2 of 2

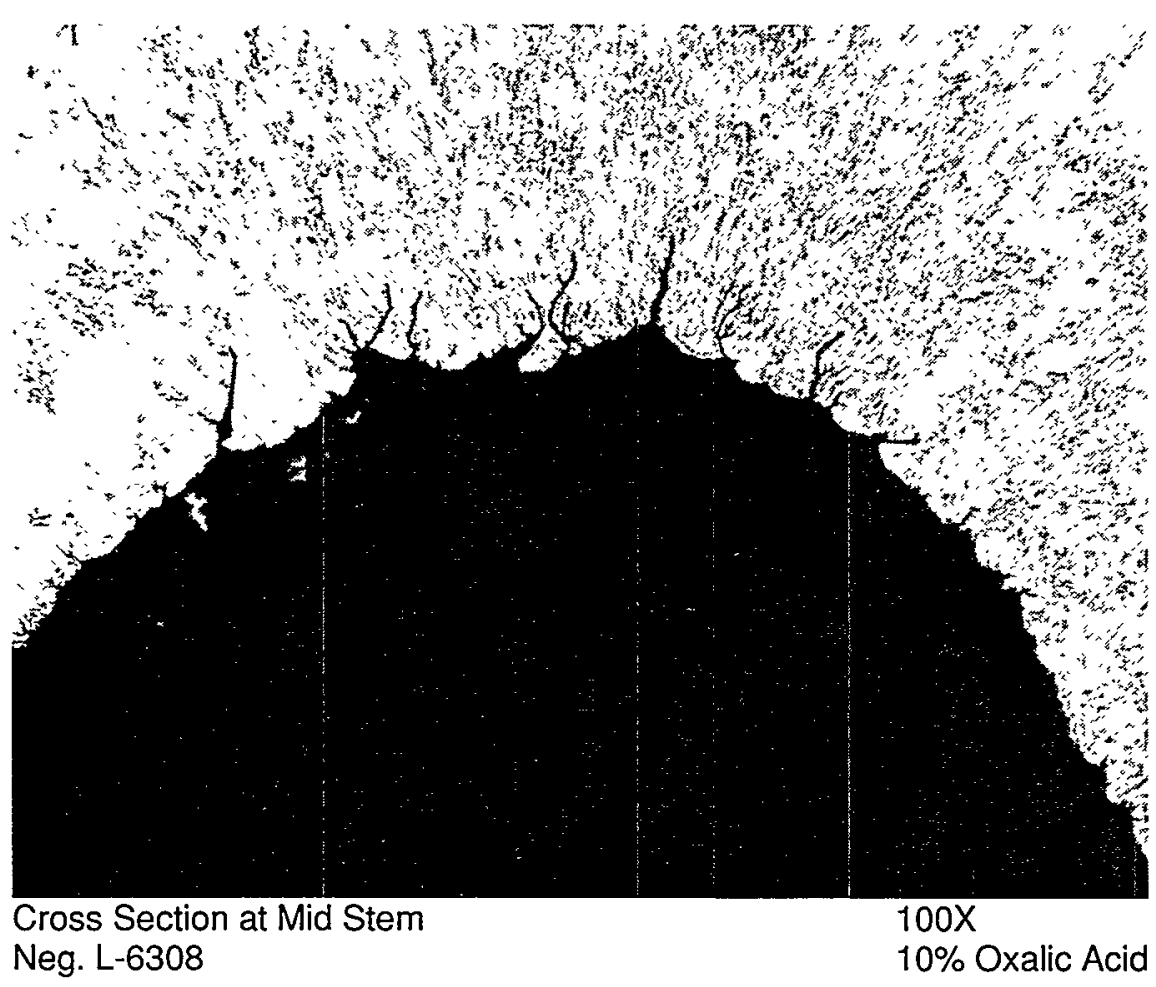


ATTACHMENT 9

METALLOGRAPHY OF BENT STEM FROM SP981 / 23350; UNAGED RESERVOIR

Test 9

$981 / 23350$

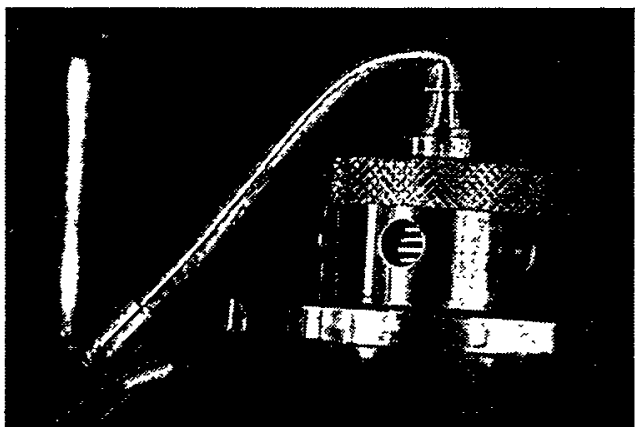

Bent Stem
Neg. $99-1038-19$

Page 1 of 2
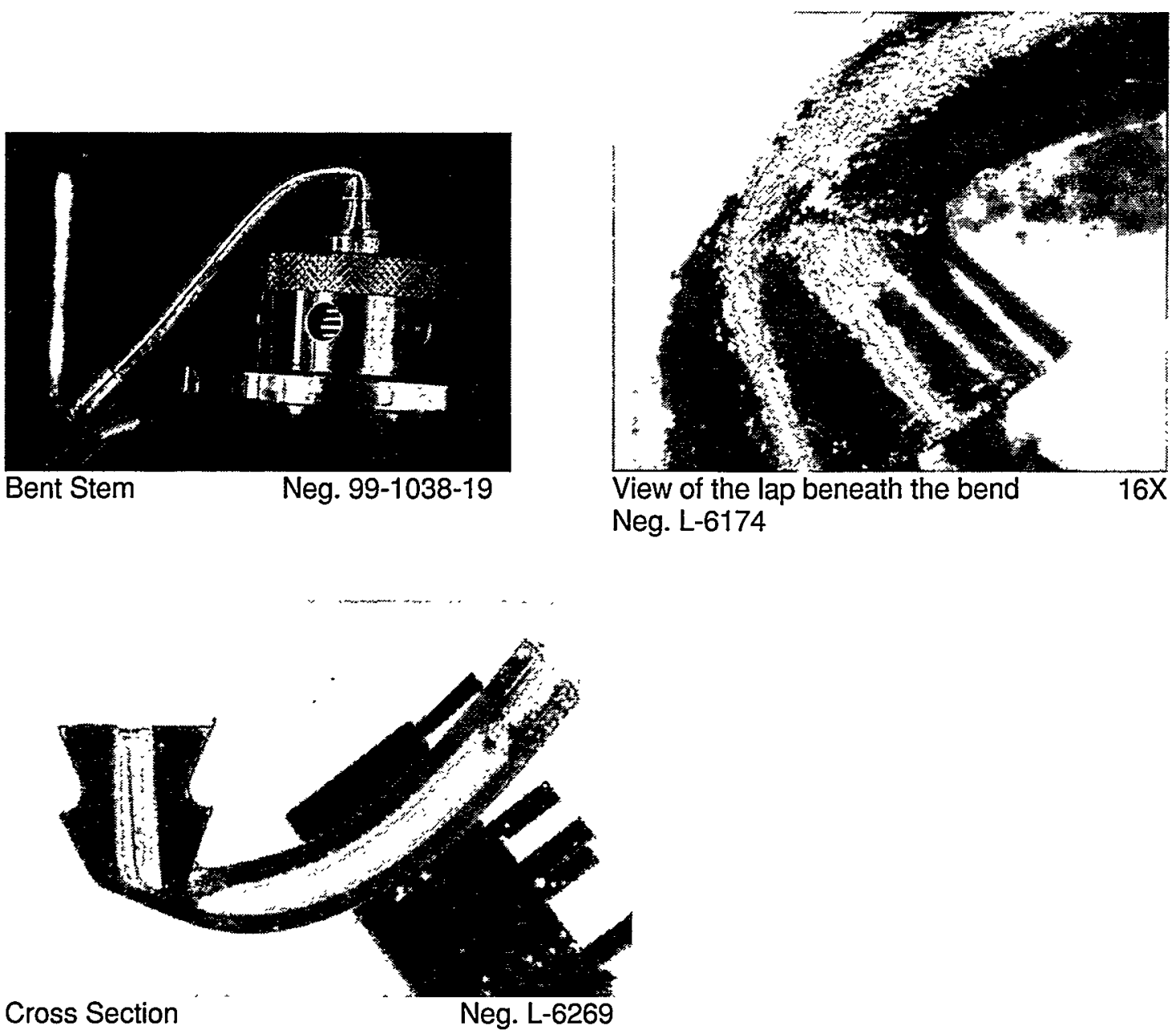
Test 9

$981 / 23350$
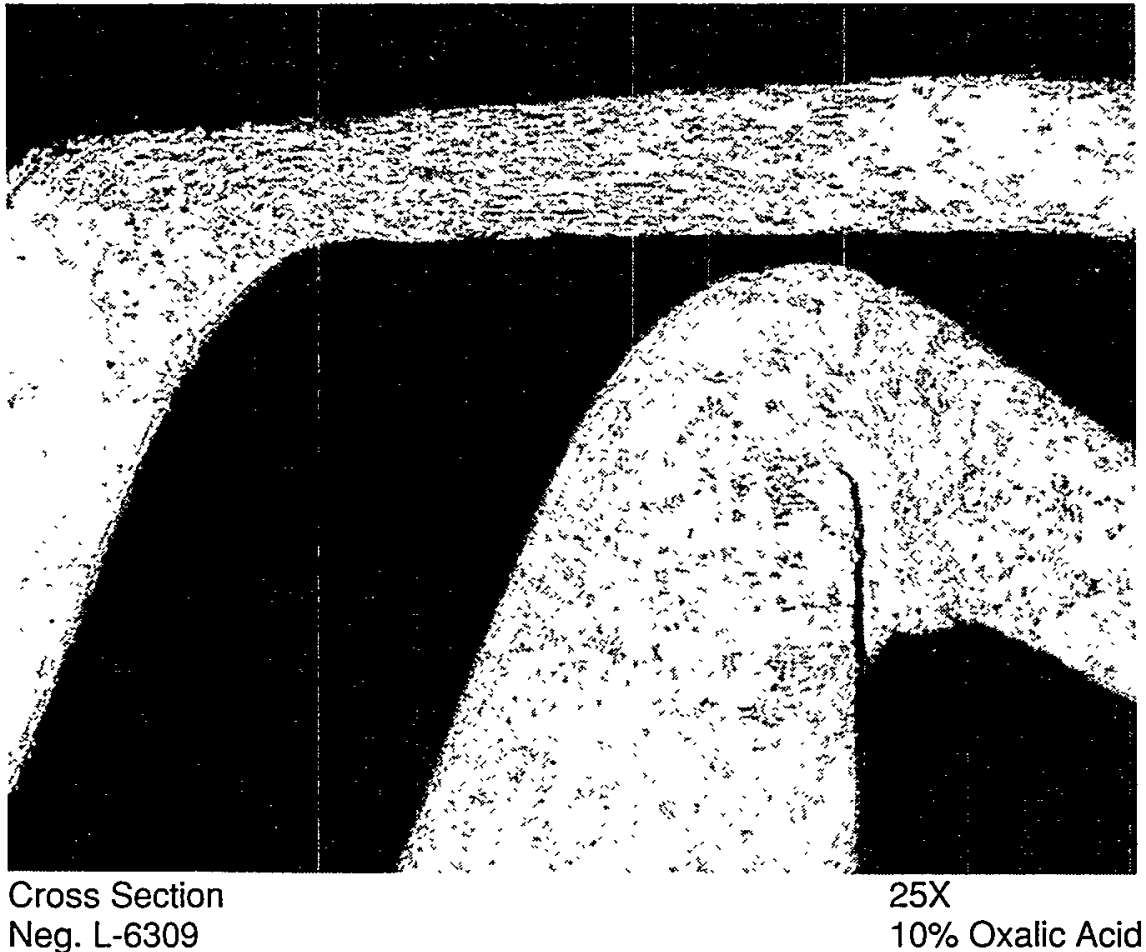

Page 2 of 2

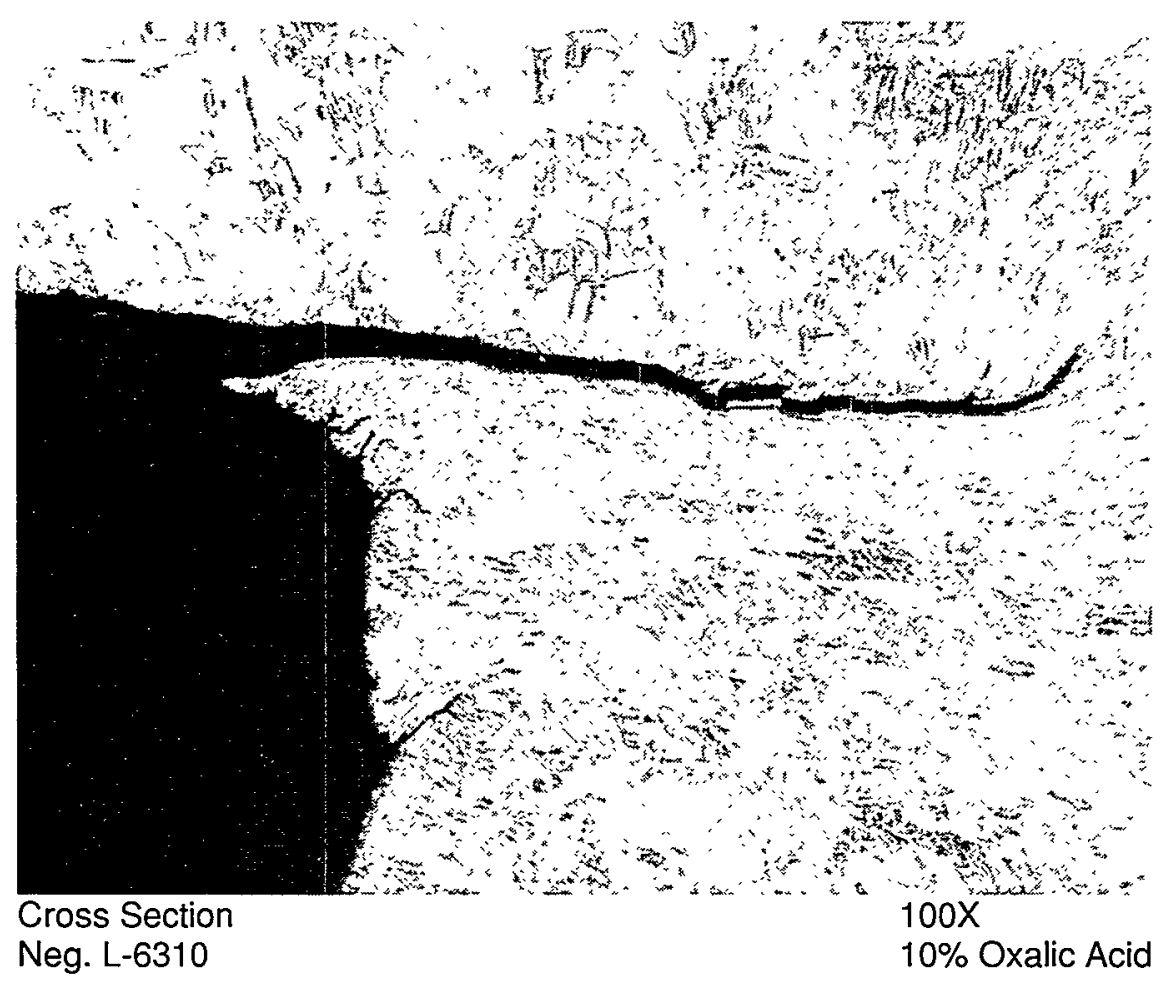


Test 10

$981 / 25826$

Page 1 of 3

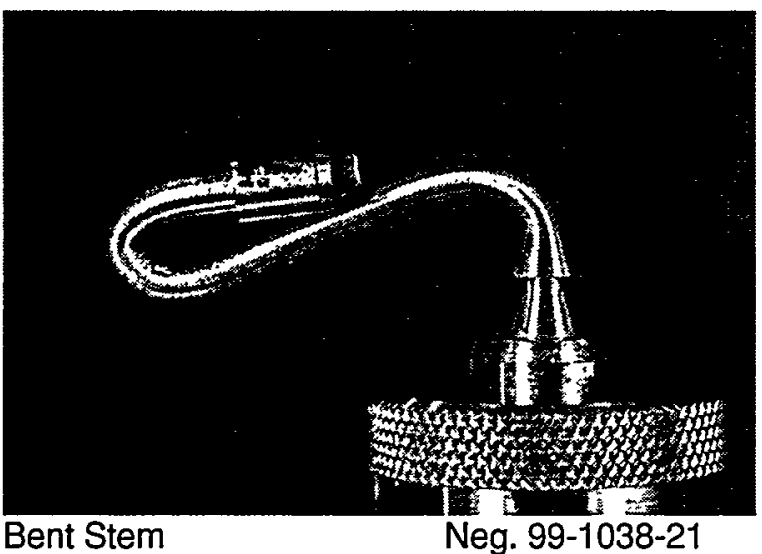

Bent Stem

Neg. 99-1038-21

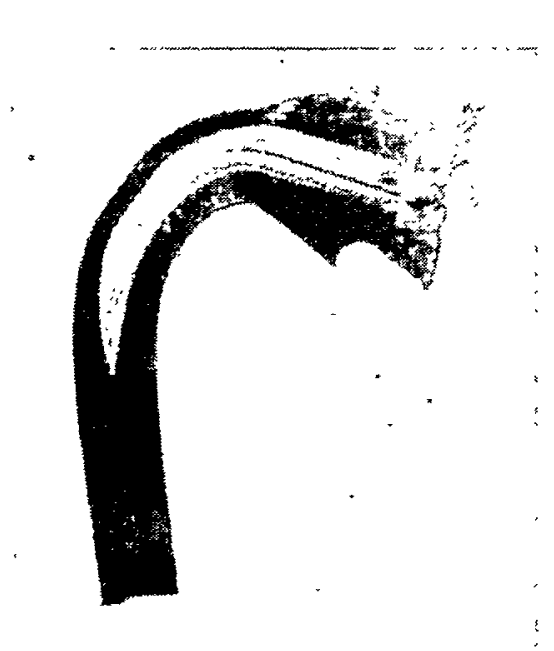

Cross Section at Cone

Neg. L-6270

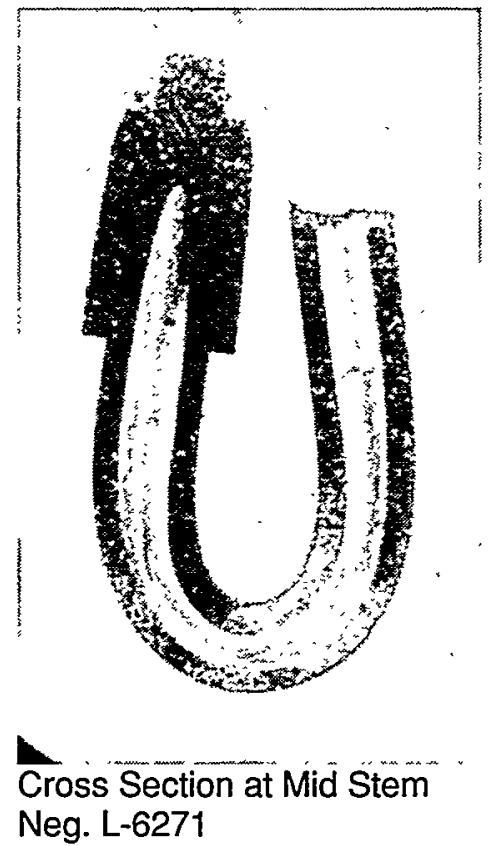

Neg. L-6271 

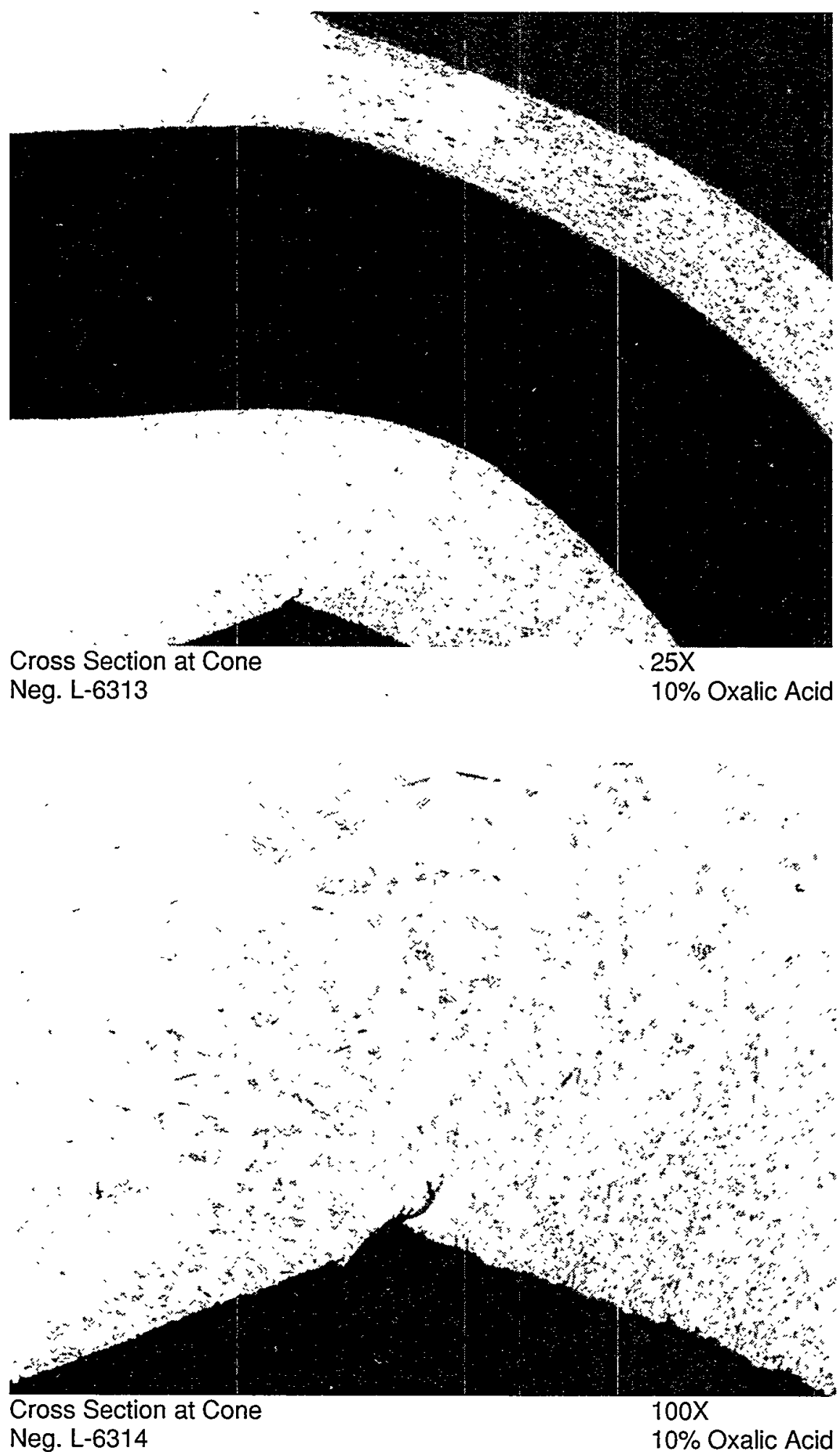
Test 10

$981 / 25826$
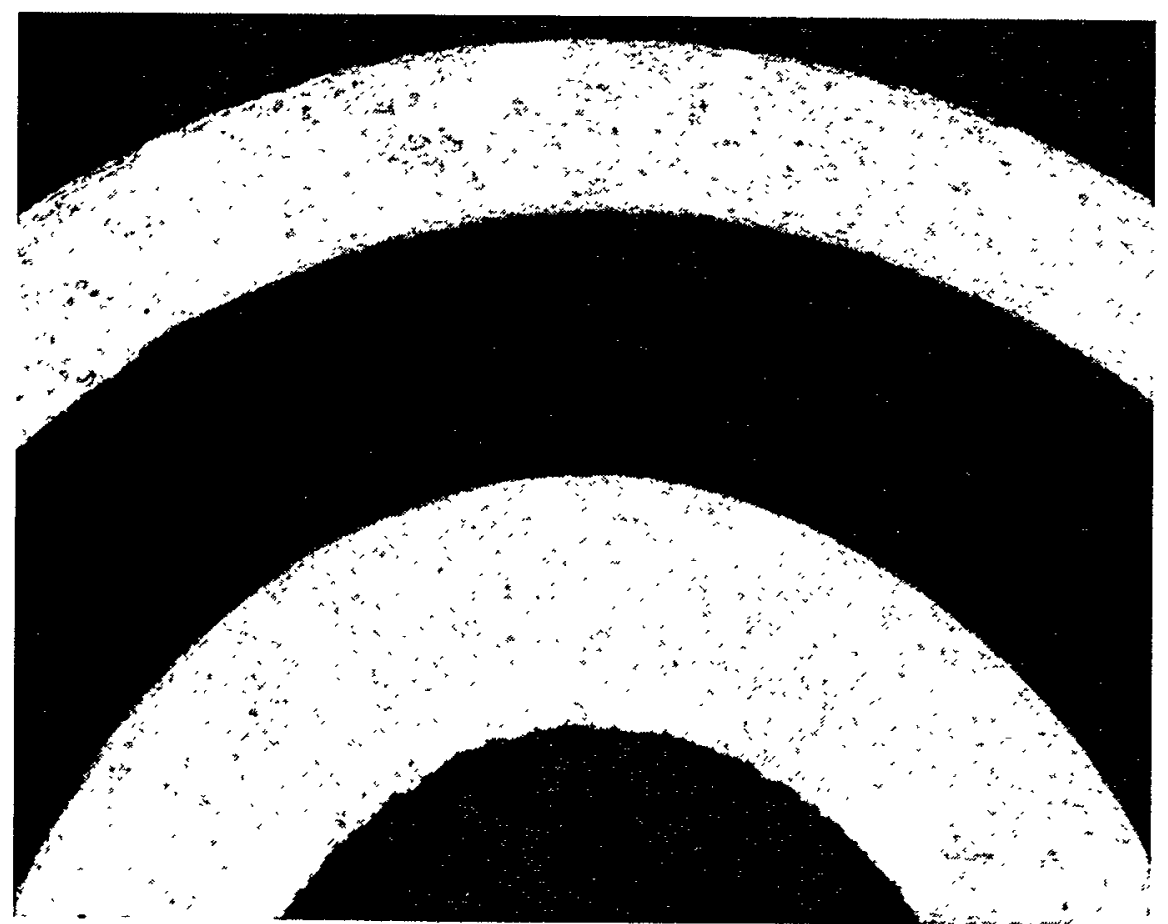

Cross Section at Mid Stem

Neg. L-6311

\section{Attachment 10 continued}

Page 3 of 3

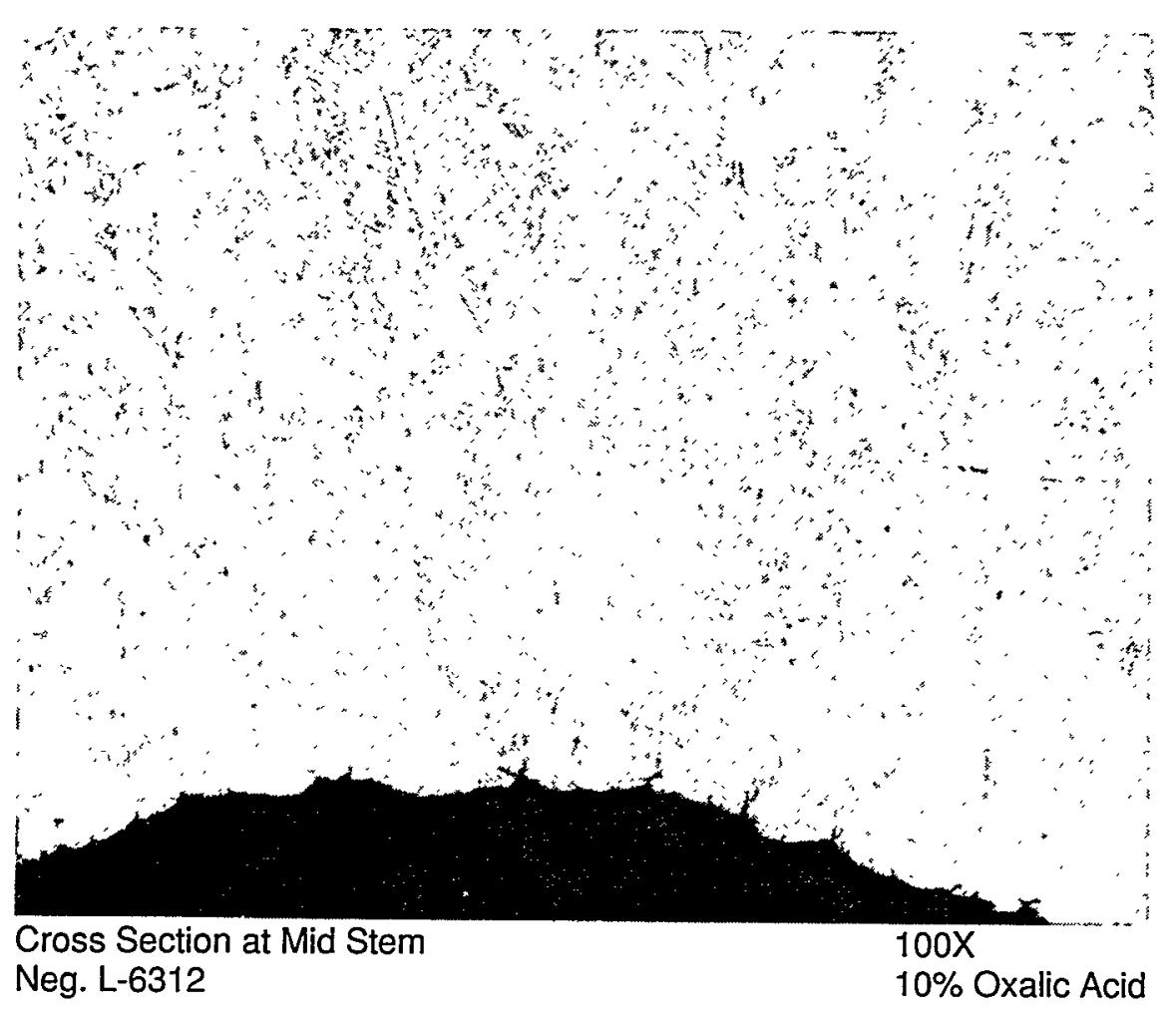




\section{(1,}

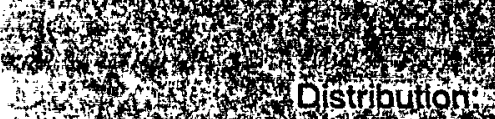

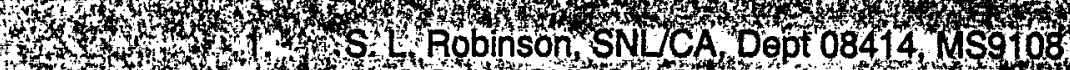

2. 1 G S Story, SNLCA Dept 08414 MS9108. R.M Gates ESAWE LANL MS 9936

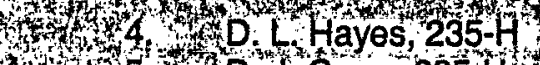

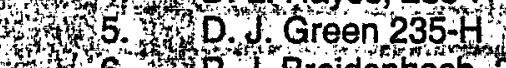

6. 1 P J Breidenbach 235-H

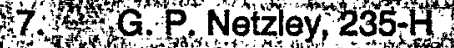

8. $\mathrm{M}$ G Giles,232-

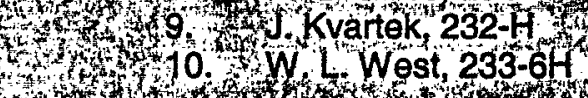

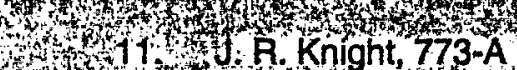

12. P F Cloessner, 773-A

13. E. J. Majzlik $773-A$

14. F, G. Caveness, 773-A

5. 5. S. Hólder, 232-H

16. 4 S. Kestin, 232-H

\% 17. 1 E.M. Vessel, 232-H

$18,0 \mathrm{~B}$. Orlowsk, 232-H

19. M B White $232-1$

H. W W 20 . Thompson, $723-A$

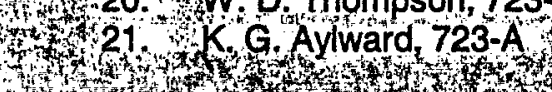

1 W22. Becords Administration, $773-52 \mathrm{~A}$

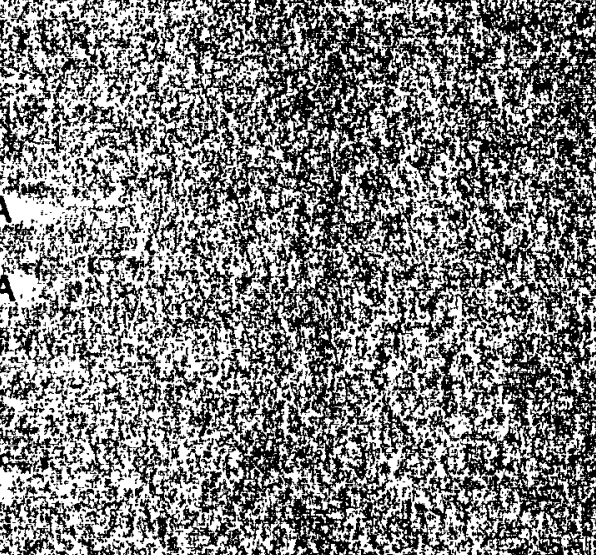

